\title{
3D modelling of the shallow subsurface of Zeeland, the Netherlands
}

\author{
J. Stafleu ${ }^{1,}{ }^{*}$, D. Maljers ${ }^{1}$, J.L. Gunnink ${ }^{1}$, A. Menkovic ${ }^{1}$ \& F.S. Busschers ${ }^{1}$
}

1 TN0 - Geological Survey of the Netherlands. Princetonlaan 6, P.0. Box 80015, NL-3508 TA Utrecht, the Netherlands.

* Corresponding author. Email: jan.stafleu@tno.nl.

Manuscript received: March 2011, accepted: December 2011

\begin{abstract}
The Geological Survey of the Netherlands aims at building a 3D geological voxel model of the upper $30 \mathrm{~m}$ of the subsurface of the Netherlands in order to provide a sound basis for subsurface related questions on, amongst others, groundwater extraction and management, land subsidence studies, aggregate resources and infrastructural issues. The Province of Zeeland (SW Netherlands, covering an area of approximately $70 \mathrm{by} 75 \mathrm{~km}$ ) was chosen as the starting point for this model due to an excellent dataset of 23,000 stratigraphically interpreted borehole descriptions.

The modelling procedure involved a number of steps. The first step is a geological schematisation of the borehole descriptions into units that have uniform sediment characteristics, using lithostratigraphical, lithofacies and lithological criteria. During the second modelling step, 2D bounding surfaces are constructed. These surfaces represent the top and base of the lithostratigraphical units and are used to place each voxel (100 by 100 by 0.5 metres) in the model within the correct lithostratigraphical unit. The lithological units in the borehole descriptions are used to perform a final 3D stochastic interpolation of lithofacies, lithology (clay, sand, peat) and if applicable, sand grain-size class within each lithostratigraphical unit. After this step, a three-dimensional geological model is obtained. The use of stochastic techniques such as Sequential Gaussian Simulation and Sequential Indicator Simulation, allowed us to compute probabilities for lithostratigraphy, lithofacies and lithology for each voxel, providing a measure of model uncertainty.

The procedures described above resulted in the first fully 3D regional-scale lithofacies model of the shallow subsurface in the Netherlands. The model provides important new insights on spatial connectivity of sediment units of, for example, sandy Holocene tidal channel systems. Our results represent a major step forward towards a fully 3D voxel model of the Netherlands.
\end{abstract}

Keywords: Holocene, lithofacies, lithology, probability estimations, stochastic modelling

\section{Introduction}

The Geological Survey of the Netherlands aims at building a 3D geological 'GeoTOP' model of the upper $30 \mathrm{~m}$ of the subsurface of the Netherlands in order to provide a sound basis for answering subsurface related questions on, amongst others, groundwater extraction and management, land subsidence studies, aggregate resources and infrastructural issues. The model provides a uniformly constructed framework for subsurface information and serves as an easily accessible data source for any subsurface activities in the Dutch delta. Earlier large-scale 3D voxel models of the Netherlands were tailor made to specific applications, i.e. aggregate resources (Van der Meulen et al., 2005) and clay resources (Van der Meulen et al., 2007).
The GeoTOP model is a fully three-dimensional, multi-purpose subsurface model of the onshore part of the Netherlands. In contrast to other nation-wide subsurface models, the Digital Geological Model (DGM; www.dinoloket.nl) and the REgional Geohydrological Information System (REGIS-II; Vernes and Van Doorn, 2005; Vernes et al., 2010; www.dinoloket.nl), the GeoTOP model is no longer a layer-based model consisting of stratigraphical or hydrogeological layers with uniform properties in the vertical direction, but a voxel model where individual voxels have uniform properties. The voxel nature of the GeoTOP model allows modelling the internal heterogeneity and property variability of the subsurface in great detail.

The GeoTOP model program was initiated in the Province of Zeeland (SW Netherlands, covering an area of approximately 
70 by $75 \mathrm{~km}$, Fig. 1) due to an excellent dataset of 23,000 borehole descriptions. The borehole descriptions were interpreted using a single lithostratigraphical scheme (Westerhoff et al., 2003), making the dataset highly consistent and therefore very suitable for the modelling. The GeoTOP model schematises the subsurface in about 50 million voxels (blocks), each measuring 100 by 100 metres in the horizontal directions and 0.5 metres in the vertical direction. Although the model includes all Quaternary, Neogene and Paleogene deposits that can be found down to a depth of 90 metres below Dutch Ordnance Datum, we will focus on the Holocene sequence of which the lower boundary reaches a maximum depth of 60 metres.

In the first part of this paper we give an overview of the geological setting and stratigraphy of the Province of Zeeland. Hereafter, the available geological datasets are described followed by a description of the GeoTOP model methods and concepts. In the middle part of this paper, results of the lithofacies, lithology and uncertainty modelling are presented followed by a section on applied products and derivatives. Finally, we discuss potential errors associated to the model procedures and datasets and give examples of possible model applications.

\section{Geology and stratigraphy}

\section{General setting}

The subsurface geology of the Province of Zeeland, in the SW of the Netherlands, has been the subject of geological studies for many years. A detailed geological mapping program was started by the Geological Survey of the Netherlands from the 1960's onward. This mapping program, postdating the catastrophic 1953 flooding of Zeeland, resulted in a suite of $1: 50,000$ scale paper maps and cross-sections (e.g., Hageman, 1964; Van Rummelen, 1965,1972 ; Vos, 1992). Because the maps have a sophisticated legend in which colours and signatures reveal the vertical succession of Holocene deposits (Hageman 1963, 1969), they can be regarded as a first step towards a 3D characterisation of the shallow subsurface (Weerts et al., 2005).

Zeeland is positioned at the southern rim of the North Sea rift basin (Fig. 1a; Ziegler, 1990, 1994; Kooi et al., 1998). The shallow subsurface geology mainly consists of gently northward dipping Neogene and Quaternary strata that were formed under shallow marine, estuarine and fluvial sedimentary conditions. The upper part of the sequence in the area is formed by Holocene deposits consisting of tidal channel, tidal flat and lagoonal sediments that alternate with peat beds and coastal shoreface and dune deposits. In the north-western part of the province, the Holocene deposits reach thicknesses of up to 20 metres. Tidal channels often incise deeply into Pleistocene deposits at depths up to 45-60 m. The Holocene deposits pinch out against the topographically higher Pleistocene grounds of Noord-Brabant to the east and Zeeuws-Vlaanderen and Belgium to the south (Vos, 1992; Vos \& Van Heeringen, 1997).

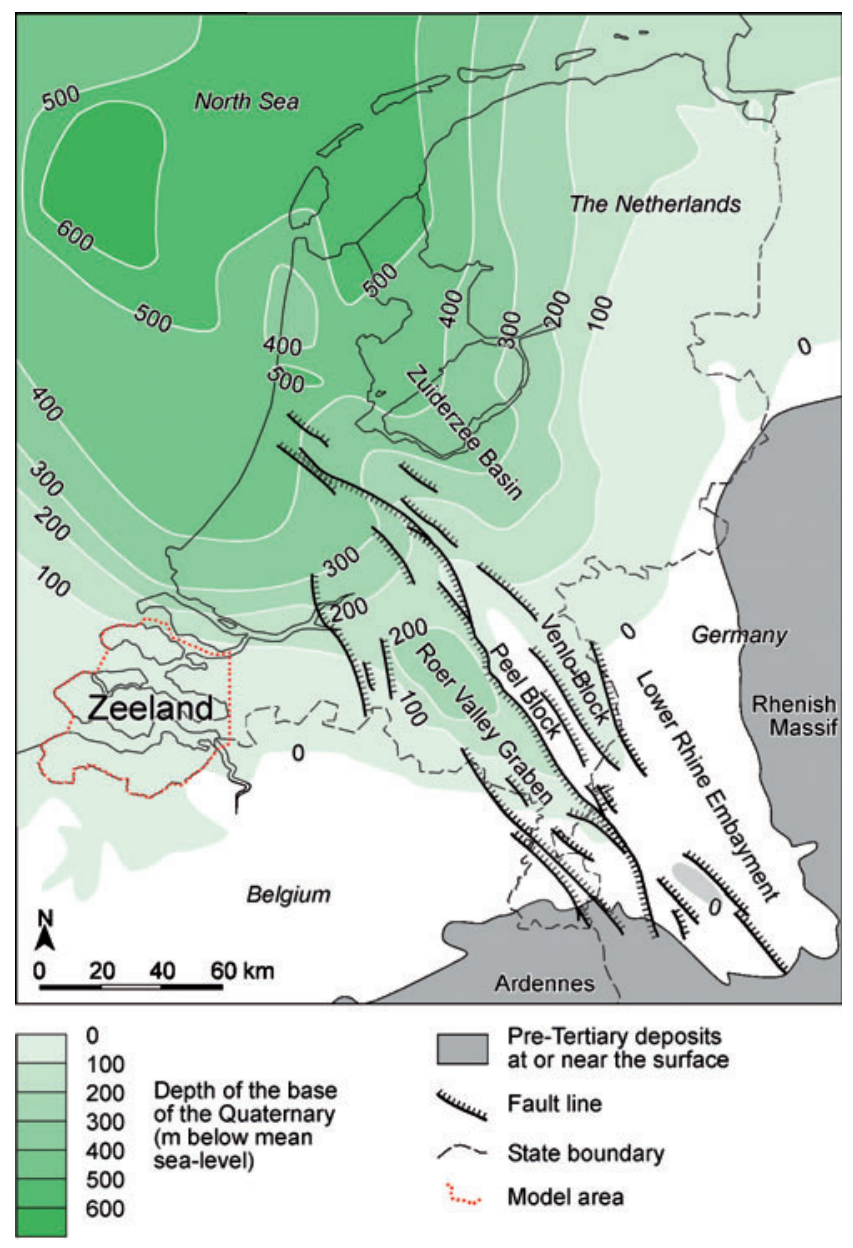

a.

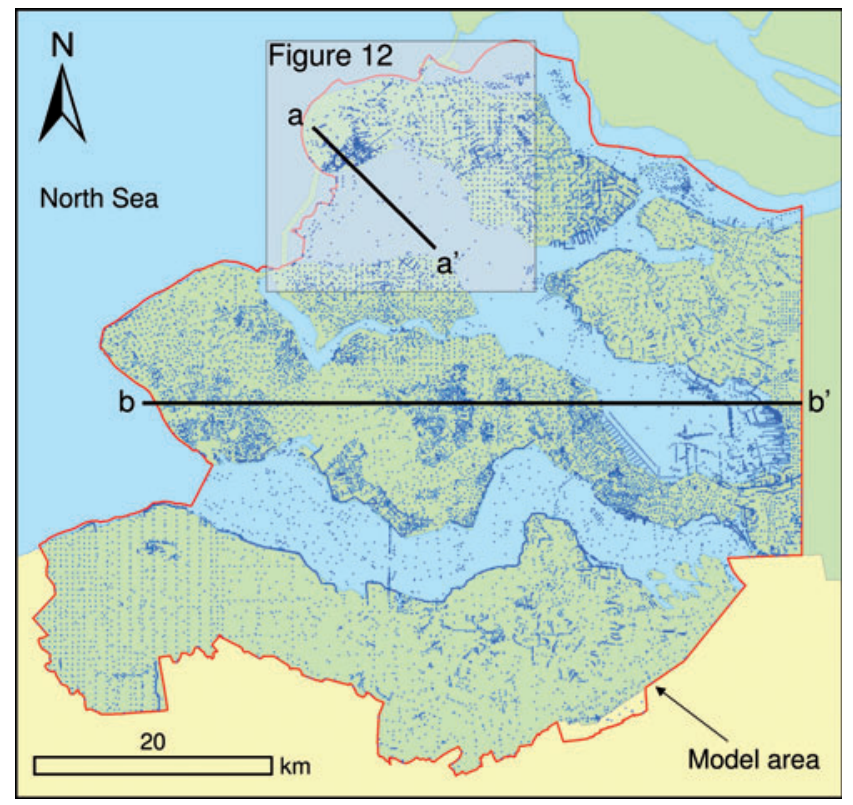

b.

Fig. 1. a. Location map showing the position of the Province of Zeeland in the south-west of the Netherlands and the depth of the base of the Quaternary in $m$ below mean sea level; $b$. Map of the Province of Zeeland showing the location of the 23,000 boreholes used in the modelling as well as the position of the cross sections of Fig. 10 and the 3D views of Fig. 12 . 


\section{Holocene stratigraphy}

In Zeeland, the first evidence of Holocene sea-level rise (after $\sim 9$ ka BP; Kiden, 1995) is represented by the formation of the Basisveen Bed (Nieuwkoop Formation; Fig. 2). The peat consists of compact, amorphous, dark brown to black peat that is compacted and hardened by the weight of the overlying Holocene sediments. Large parts of the Basisveen Bed were removed by erosion by Holocene channels.

The Basisveen Bed is covered by a complex of tidal, lagoonal and coastal barrier sediments of the Naaldwijk Formation (Vos, 1992; Vos \& Van Heeringen, 1997; Westerhoff et al., 2003). The tidal and lagoonal sediments consist of two Members (Wormer and Walcheren Member) that are separated by a distinct peat level (Hollandveen Member; Nieuwkoop Formation) (Fig. 2).

The sediments of the Wormer Member were deposited between \%-5 ka BP under conditions of an open coast with large tidal inlets and significant tidal amplitudes (Beets \& Van der Spek, 2000). The Wormer Member is heterogeneous in composition and consists of lagoonal, tidal channel and tidal flat deposits. The tidal deposits are made up of clayey sands and fine sands whereas the lagoonal sediments mainly consist of clay and sandy clay. The sands in the tidal channels are slightly coarser than those in the tidal flats. It is often difficult to distinguish the latter two deposits on the basis of borehole descriptions alone. The overlying Hollandveen Member consists of a several metres thick peat layer. The peat formed in a freshwater marsh after closure of the coastal barrier and silting up of the tidal inlets from 6 ka BP onwards (Beets \& Van der Spek, 2000).

During formation of the younger Walcheren Member, representing a new phase of marine inundation after $\sim 2 \mathrm{ka} B \mathrm{P}$, large parts of the Wormer Member and overlying Hollandveen Member were eroded (Vos \& Van Heeringen, 1997). The Walcheren Member consists of thin, clayey tidal flat deposits and thick, sandy tidal channel deposits that fill channels deeply incised into older sediments. Tidal flat deposits are abundant at the present-day surface of Zeeland. These deposits are thin (1-5 metres) and underlain by peat of the Hollandveen
Member. Thin sand layers $(0.5-5 \mathrm{~cm})$ are frequently observed within the clays. Tidal channels are thick (5-45 metres) and filled with fine sand. At the bottom of the deeper channels like the Westerschelde, channel lags consisting of shells and shell-rich sands occur.

The coastal deposits of the Naaldwijk Formation are subdivided into the Zandvoort and Schoorl Members. These units border the tidal Wormer/Walcheren and organic Hollandveen Member in the west. The Zandvoort Member consists of (coastal barrier) shoreface deposits, made up by fine to medium sand. Aeolian dune deposits belong to the Schoorl Member and consist of fine to medium sand. Within the coastal deposits, thin peat layers with a limited lateral extent may occur that are (undifferentiated) part of the Nieuwkoop Formation.

Especially at the location of major towns and in industrial areas the Holocene sediments are covered by anthropogenic deposits of several $\mathrm{dm}$ to metres in thickness. The lithological composition of these deposits varies considerably over short distances.

\section{Pleistocene, Neogene and Paleogene stratigraphy}

Pleistocene deposits underlie the Holocene sequence in the major part of the province. The upper part of the Pleistocene (if not eroded by Holocene tidal channels) consists of periglacial and aeolian sands and silts of the Boxtel Formation (Van Rummelen, 1965; Schokker et al., 2007). Older Pleistocene Formations include the Eem Formation (fine- to mediumgrained marine sands with shell fragments) and the Waalre Formation (fine- to medium-grained estuarine sands and clay layers) (Kasse, 1988; Vos, 1992; Vos \& Van Heeringen, 1997; Westerhoff, 2009), the latter forming a conspicuous escarpment in the eastern part of the Province (right-hand side in Fig. 2). In the shallow subsurface of Zeeuws-Vlaanderen and at greater depths $(>100 \mathrm{~m})$ in other parts of the Province, Neogene and Paleogene shallow marine deposits occur. These deposits consist of fine- to medium-grained sands and clays that are

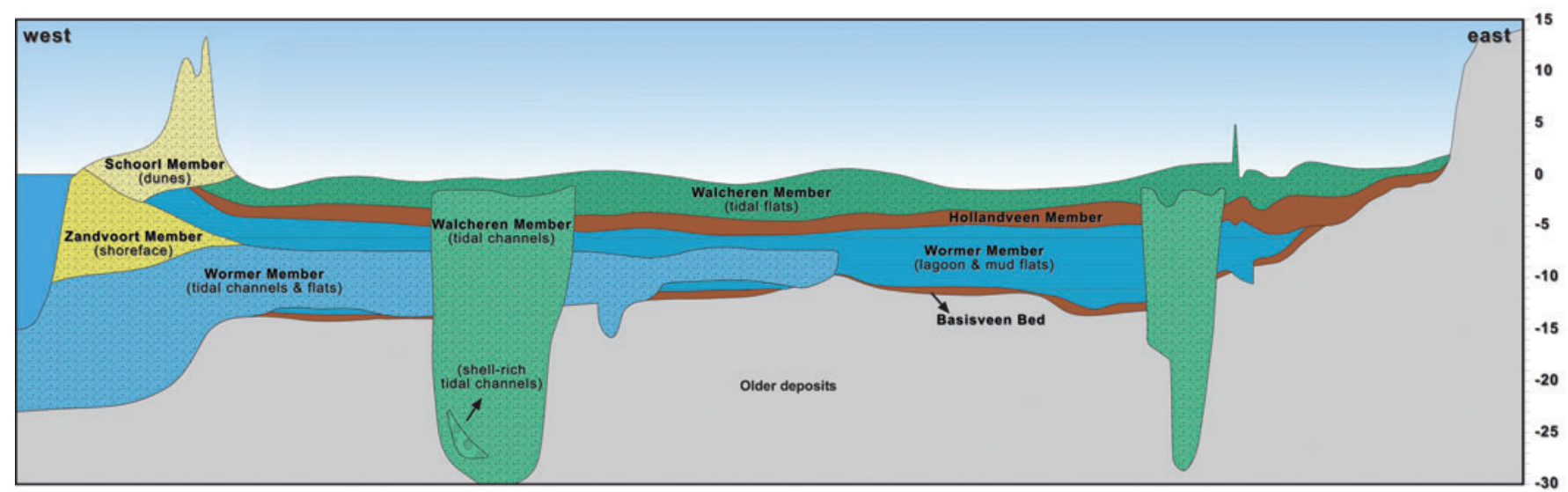

Fig. 2. Schematic cross section through the Holocene deposits in the Province of Zeeland, showing the lithostratigraphical and lithofacies units and their cross-cutting relationships. The horizontal distance is about $70 \mathrm{~km}$, the vertical distance runs down to 30 metres below Dutch Ordnance Datum. 
often rich in glauconite (Van Rummelen, 1965). A marked, hydrologically nearly impermeable unit is the Oligocene age Rupel Clay Member (Rupel Formation) consisting of stiff brown clays.

\section{Methods}

\section{Data}

Outcrops in Zeeland are limited to the coastal areas and a few former quarries in the south. Therefore, mapping and modelling geology strongly relies on borehole information. For the Province of Zeeland, a total of 23,000 borehole descriptions are available in the DINO-database, a digital archive of subsurface data of the Netherlands that has been developed and is being maintained by TNO - Geological Survey of the Netherlands (www.dinoloket.nl) (Fig. 1b). All boreholes are stored using a standardised coding method (Bosch, 2000), which facilitates automated handling and analysis of large amounts of borehole data. The database contains manually drilled auger holes (5-10 m depth) as well as mechanically drilled holes (commonly deeper than 20 metres). Fig. 3 shows that much more data is available for the shallow subsurface (mainly penetrating the Walcheren and Hollandveen Members) than for deeper units.

The most important attributes of the DINO borehole descriptions that are used in the modelling procedure include top and bottom of the borehole intervals, main lithology, admixtures of sand, silt and clay, sand median, shell content and sediment structures. Most parameters are expressed as

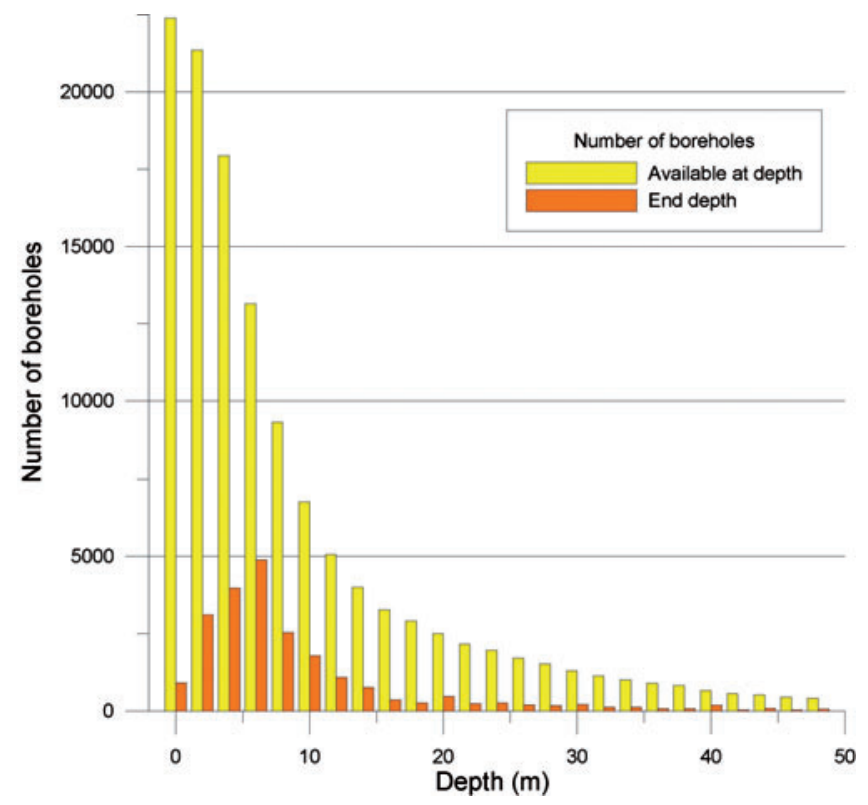

Fig. 3. Histograms showing the number of boreholes that is available at a certain depth along with the number of boreholes that reaches a certain end depth. $N=23,000$; interval range $2 \mathrm{~m}$. The spatial distribution of the boreholes is shown in Fig. 1 b. distinct classes rather than in numerical values. For the model area, all 23,000 DINO boreholes have a lithostratigraphical interpretation following the classification scheme of Westerhoff et al. (2003). After quality control of the data, some 525 (2.3\%) boreholes were excluded from the modelling. The high data density and interpretation of this data using a single lithostratigraphical scheme resulted in a highly consistent dataset that (at that time) was unavailable for other areas.

The upper boundary of the Zeeland model is defined by the 5 by $5 \mathrm{~m}$ cell size national airborne laser altimetry survey dataset (AHN; www.ahn.nl). We used in-house developed software to remove buildings (rooftops) and foliage from the data and subsequently resampled the data to a 100 by $100 \mathrm{~m}$ cell size. Information on water depths of rivers, canals and estuaries was obtained from bathymetric survey data.

Existing digital geological modelling results (raster layers) of the DGM and REGIS models were used in order to define the maximum lateral extent of each lithostratigraphical unit. These same raster layers were used as trend surfaces in the 2D modelling procedure. The DGM rasters were used for the Pleistocene and older formations while the REGIS rasters were used for the Holocene units.

\section{Modelling procedure}

The modelling procedure is schematised in Fig. 4. Firstly, the lithological data from each borehole were converted into lithofacies units using newly developed software (lithofacies interpretation). Examples of lithofacies units include tidal channels, tidal flats and coastal dunes. Hereafter the boreholes were subdivided in lithological units (clay, sand, peat), and units of uniform sand grain size (lithological classification). Subsequently, the 2D top and basal surfaces of lithostratigraphical units were constructed that allowed placing each voxel within a correct lithostratigraphical context at formation and member level (2D lithostratigraphical modelling). A resolution (voxel size) of 100 by 100 by $0.5 \mathrm{~m}$ was chosen based on the density of the data available and the regional nature of the model. Furthermore, the horizontal dimensions of the voxels match the raster cell size of DGM and REGIS. The last step in the modelling procedure involved a $3 \mathrm{D}$ interpolation procedure in order to construct both a 3D lithofacies model and a 3D lithological model (3D lithofacies and lithological modelling). A detailed description of each of these steps is given below.

\section{Lithofacies interpretation}

Lithofacies represent all sediment characteristics (for example lithology, primary sedimentary structures and the dimensions of the sedimentary unit) that result from the depositional environment in which the sedimentary unit was formed (Miall, 1999). The concept of lithofacies was used to model the internal heterogeneity of the lithostratigraphical units (Schokker \& 

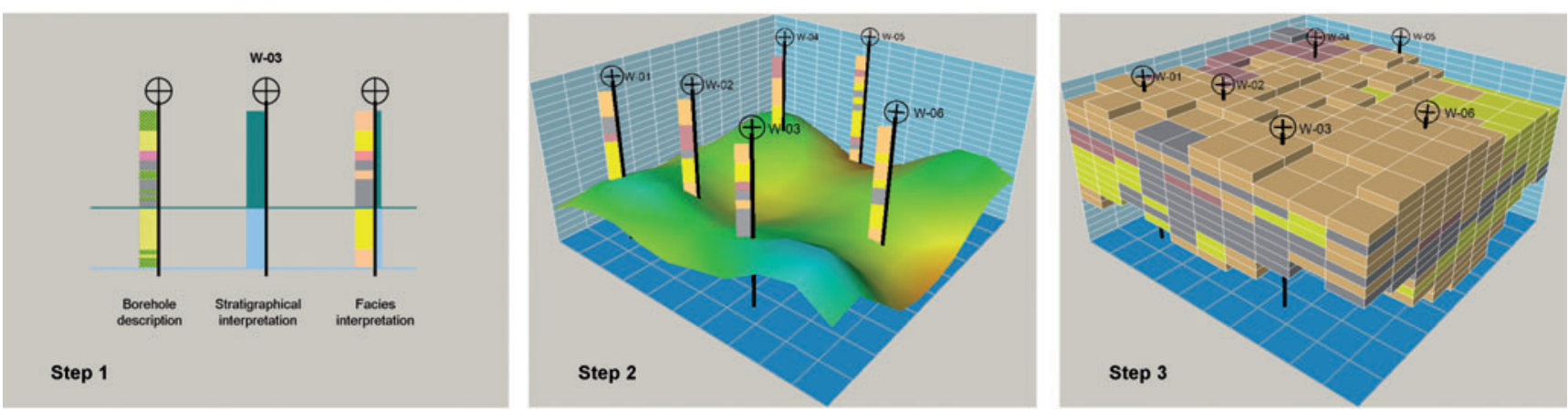

Fig. 4. Basic modelling procedure. Step 1: Borehole descriptions subdivided into lithostratigraphical, lithofacies and lithological units. Step 2: 2D interpolation of the basal surface of each lithostratigraphical unit. Step 3: 3D interpolation of lithofacies and lithology within each lithostratigraphical unit.

Weerts, 2004). This resulted in identification of 17 different lithofacies units, of which 7 were identified in the Holocene deposits (Fig. 2).

All intervals of the Nieuwkoop Formation were assigned the marshes lithofacies. An attempt was made to further subdivide the marshes lithofacies, but this turned out to be only possible in a few isolated areas of the province.

In the Wormer Member, the clayey lagoonal lithofacies was distinguished from the sandy tidal channels and tidal flats by the difference in main lithology. Sandy intervals with a sand median smaller than $100 \mu \mathrm{m}$ and with intercalated clay layers were also allocated to the lagoonal lithofacies. Using the data available in the DINO borehole descriptions, it was not possible to distinguish between the tidal flats and tidal channels of the Wormer Member.

For the Walcheren Member, the assignment of the lithofacies was more complex. In cases of an underlying Hollandveen Member, the borehole intervals of the Walcheren Member were classified as tidal flats, because of the unlikelihood that a tidal channel developed without eroding the Hollandveen Member. In cases where the Hollandveen Member is absent, the depth of the lowermost clay layer is determined. Intervals above this clay layer are classified as tidal flats, and intervals below as tidal channels. In cases where neither clay nor the Hollandveen Member was present, the occurrence of underlying clay layers of the Wormer Member was used as another criterion to classify the Walcheren Member as tidal flats. If none of the three criteria above is applicable (i.e. no indications of tidal flats were found), the entire sequence of Walcheren layers was classified as tidal channel. The last criterion involved the presence of shells and shell-rich sands with a total thickness of at least 1 metre. These layers were classified as shell-rich channel lag deposits.

For the Schoorl Member, most intervals belong to the single lithofacies aeolian dunes, except for intercalating layers of peat, which are assigned a marshes lithofacies. All intervals of the Zandvoort Member are simply assigned the beach and shoreface lithofacies. No lithofacies unit was assigned to the anthropogenic deposits.

We developed software (written in Python; www.python.org) to apply the criteria for distinguishing lithofacies within lithostratigraphical units to all 23,000 boreholes automatically. Using software not only saves time, but also guarantees a consistent and repeatable interpretation of lithofacies.

\section{Lithological classification}

A computer program was developed to assign a lithological class to each interval in the boreholes and to assign a grainsize class to sandy intervals. The program follows the classification scheme of REGIS (Vernes \& Van Doorn, 2005), resulting in lithological classes that are suitable for groundwater modelling. No lithological classification was applied to the anthropogenic deposits. The classification scheme is summarised in Table 1.

Table 1. Lithological and sand grain-size classes used in the Zeeland modelling study.

\begin{tabular}{ll}
\hline Lithological class & Grain size \\
\hline Organic deposits & N/A \\
Clay & N/A \\
Clayey sand and sandy clay & N/A \\
Fine sand & $63-150 \mu \mathrm{m}$ \\
Medium sand & $150-300 \mu \mathrm{m}$ \\
Coarse sand, gravel and shells & $>300 \mu \mathrm{m}$ \\
Sand, grain size unknown & Unknown \\
\hline
\end{tabular}

\section{D lithostratigraphical modelling}

2D lithostratigraphical top and basal raster surfaces of both the Holocene and older deposits were already available from the REGIS and DGM models respectively. These surfaces were updated by fitting them to the 23,000 boreholes that were available for the Zeeland area. The fitting was performed by calculating residuals and a subsequent interpolation step.

Firstly, the depth of the base of each lithostratigraphical unit in each borehole was compared with the depths of the corresponding REGIS/DGM (base) raster surfaces. These basal surfaces of REGIS and DGM were taken as the best estimate of 
the depth of the lithostratigraphical unit on a regional scale. The surfaces were constructed taking into account a selection of the best borehole descriptions, combined with expert knowledge about the geological history of the area. The differences between the depth of the regional surface and the boreholes, the so-called 'residuals', represent a measure of how well the surface fits to the data, and were subsequently interpolated using Sequential Gaussian Simulation (SGS) (Goovaerts, 1997). The simple kriging algorithm was used, in which the model-mean was set to 0 . SGS estimates the residual value at a given location based on the values of the data points in a circular search neighbourhood and a variogram model describing the spatial correlation. The variogram model ensures that the data most closely correlated with the target cells are given the greatest weight in the interpolation. As an example, a variogram of the residuals of the base of the Walcheren Member is shown in Fig. 5a.

The simulations were carried out using the Isatis modelling software package (www.geovariances.com) and resulted in 100 different realisations of statistically equally probable residual variations. From these realisations, a mean residual surface was calculated. By adding this surface to the original REGIS/DGM basal (or trend) surfaces a new basal surface (or updated REGIS/DGM surface) was created for use in the remainder of the modelling process. By using the standard deviation of the 100 Sequential Gaussian Simulation (SGS) we calculated the probability that each voxel is part of the lithostratigraphical unit, giving an indication of model uncertainty. Although we could have used kriging to interpolate the residuals, this would not have given us the opportunity to construct multiple, equally probable 2D lithostratigraphical models, which is possible with the SGS method. In the next step, an integrated layer model was constructed that incorporated all of the newly created basal surfaces as well as known stratigraphical order and cross-cutting relationships (Fig. 2). Several critical decisions were made during construction of this model. Firstly, in situations where a thin occurrence of the Basisveen Bed would be intersected by an overlying unit, we assigned a minimum thickness of 0.5 metres to the Basisveen Bed below the base of the overlying units. This was done to in order to prevent the Basisveen Bed, regarded as a key unit in Holocene stratigraphy, to be largely removed during model construction. Secondly, we decided to combine the Wormer and Zandvoort Members in a single (combined) Wormer-Zandvoort Member. This was done due to the complex interfingering pattern of these two units in the coastal areas that is difficult to model in 2D. Since the two members do differ in lithofacies composition, we were able to distinguish them again in a later phase of the modelling process (lithofacies modelling).

After completion of the layer model, the basal and top surfaces (the latter being defined by overlying basal surfaces) were used to assign the correct lithostratigraphical unit to each voxel within the 3D model space.

\section{D lithofacies modelling}

The lithofacies units in the boreholes were used as a basis for 3D interpolation of lithofacies within each lithostratigraphical unit. For this, we used Sequential Indicator Simulation (SIS; Goovaerts, 1997), using the Isatis modelling software package. SIS was applied to all units except the homogeneous units of the Hollandveen Member and Basisveen Bed that were simply assigned a single lithofacies. Sequential Indicator Simulation, based on indicator kriging formalism, was used because it is a well established method to simulate lithofacies distributions, it requires modest computation time and is straightforward to implement. Order relation problems are not occurring when using indicator kriging for lithofacies interpolation and simulation,

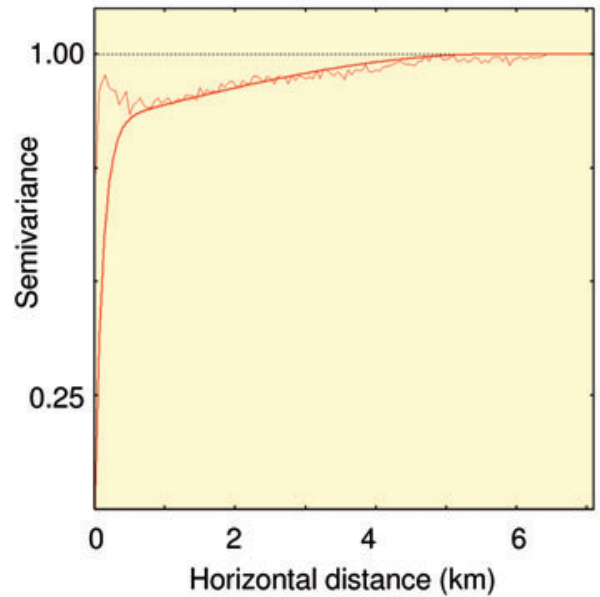

a.

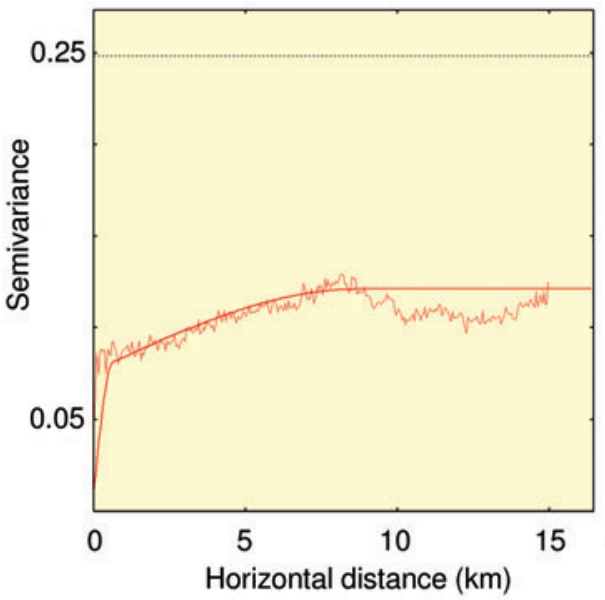

$b$.

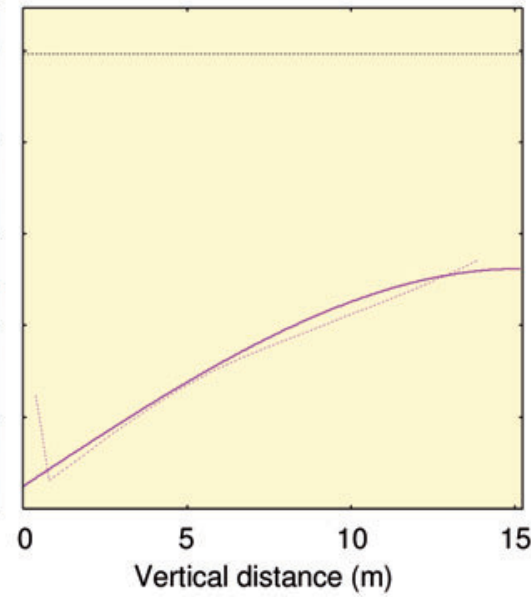

c.

Fig. 5. Examples of variograms of the Walcheren Member: a. Experimental (wiggly line) and fitted (solid line) variogram of the residuals of the base of the member used in the 2D interpolation; $b$ and c. Experimental and fitted variograms of the tidal flat lithofacies in (b) the horizontal and (c) vertical direction used in the $3 D$ lithofacies modelling. 
since there is no inherent order in the lithofacies that are simulated. Probabilities below 0 and more than 1 are simply reset to 0 and 1 respectively. SIS remains the most commonly used method of simulating facies. The modelling described in this paper is not experimental, but is mainly the application of established modelling methods on a large scale with a large amount of borehole data. We therefore did not consider at the time of starting the modelling more experimental methods like Bayesian Maximum Entropy (Bogaert, 2002) or Multiple Point Statistics (Strebelle, 2002).

In SIS, the borehole data are first migrated to the closest voxel and considered as hard data afterwards (marked ' $D$ ' in Fig. 6). All the remaining voxels are scanned using a random path. A neighbourhood is established, centred on the target voxel (marked '?' in Fig. 6). Within this neighbourhood, the procedure searches for the hard data from the boreholes and for voxels that are already simulated (marked 'S' in Fig. 6). The neighbourhood is searched using a variogram model which ensures that the data most closely correlated with the target voxels are given the greatest weight (Figs $5 \mathrm{~b}$ and $\mathrm{c}$ ). The data are then coded into a set of indicators (hence the name indicator simulation). For each lithofacies unit, the indicator is set to 1 if the data belongs to the lithofacies unit and to 0 if not. The next step in SIS consists of a co-kriging phase (block kriging) taking into account the previous information, resulting in a probability between 0 and 1 for each lithofacies unit. The values are plotted in a cumulative distribution function (marked 'CDF' in Fig. 6). Then a random value between 0 and 1 is drawn and compared to the cumulative distribution function. The simulated lithofacies at the target voxel corresponds to the rank of the interval to which the random value belongs.

Especially in the deeper parts of the model, the neighbourhood search at a target voxel may end up with no data (neither hard data from boreholes nor already simulated voxels). The result is then drawn from proportions. These are the global proportions of each lithofacies unit observed in the boreholes which are assumed to be constant throughout the lithostratigraphical unit. In case of the Wormer-Zandvoort and Walcheren Members, we decided to apply a vertical proportion curve (VPC) rather than a global proportion. A VPC was necessary because the shallow boreholes overestimate the global proportion of the shallow tidal flat clays. The VPC describes the expected proportion as a function of depth. At shallow depths, the VPC shows a high proportion of tidal flat lithofacies and a low proportion of tidal channel lithofacies, at greater depths the situation is reversed (Fig. 7).

The SIS resulted in 50, statistically equally probable simulations of lithofacies distributions. From these simulations probabilities of occurrence for each lithofacies were calculated giving an indication of model uncertainty. In addition, probabilities were used to compute a mean lithofacies model using the averaging method for indicator datasets described by Soares (1992). However, the individual simulation results remain available for further use in e.g. groundwater modelling.

\section{D lithological modelling}

Basically the same interpolation procedure as when modelling lithofacies was used to construct a 3D lithological unit model. In case of the Schoorl and Hollandveen Members and the Basisveen Bed, lithological units were interpolated for each lithostratigraphical unit separately and independently from lithofacies. However, in case of the Wormer-Zandvoort and Walcheren Members, we decided to use the results of the lithofacies interpolation and perform a 3D interpolation within each lithofacies unit. The lithology that occurs in the lithofacies varies considerably: both sandy and clayey units occur within the lithofacies of both the Wormer-Zandvoort and the Walcheren Members, with the tidal channel lithofacies being more sandy and the tidal flat lithofacies often showing a fining upward trend. Since the lithofacies units and the lithological units do not have a straightforward correlation, we decided to
Fig. 6. Two different simulations of lithofacies at the same target grid cell using Sequential Indicator Simulation. See text for discussion. CDF $=$ Cumulative Distribution Function .
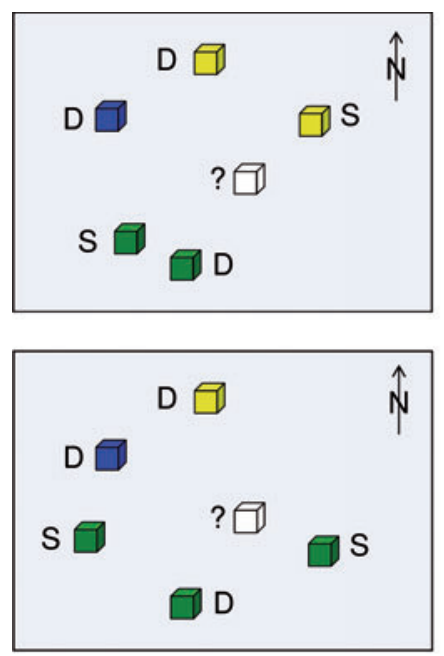

Conditioning data
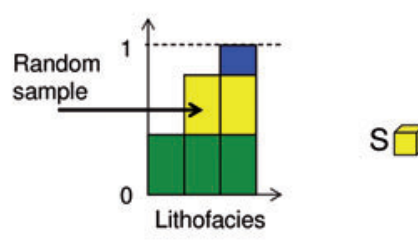

Simulation 1

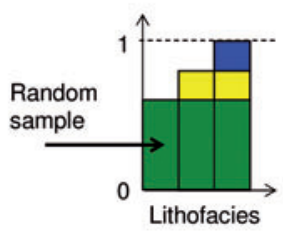

s

Simulation 2

CDF at location (?)

Value at location (?) 


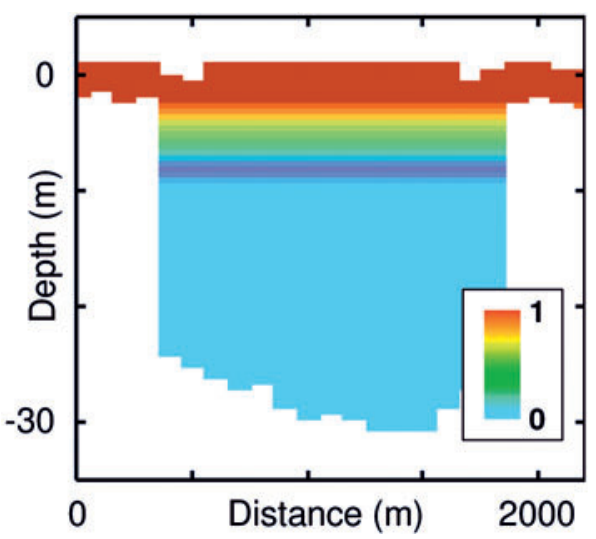

a.

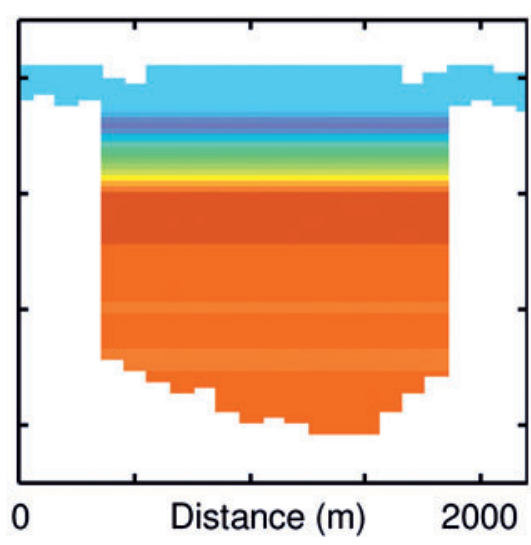

$b$.

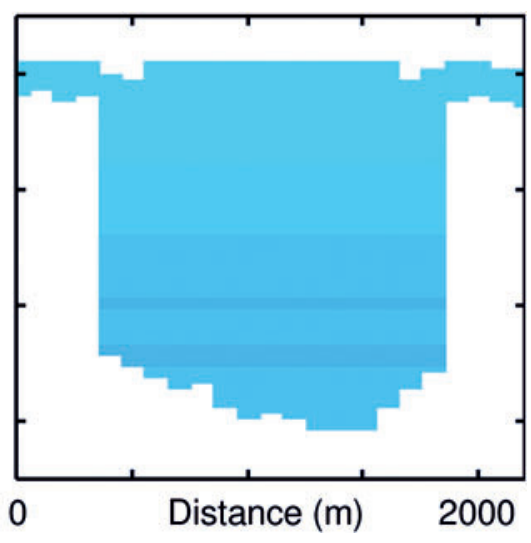

c.

Fig. 7. Vertical Proportion Curve (VPC) of the Walcheren Member describing the expected proportion of lithofacies units as a function of depth: a. Tidal flat; $b$. Tidal channel; and c. Shell-rich tidal channel lithofacies. At shallow depths, the VPC shows a high proportion of tidal flat lithofacies and a low proportion of tidal channel lithofacies, at greater depths the situation is reversed. The VPC is used when the neighbourhood search at a target voxel ends up with no data.

model them separately, in which the lithological units are treated independently from the lithofacies units.

In case of the sand grain sizes, the borehole data included intervals that have a described lithology 'sand' but lack grain-size data. We solved this problem by dividing the interpolation procedure into a number of steps. First, we calculated 10 simulations of the distribution of sand versus non-sand sediment, using all the borehole data available. Then, for each of the 10 simulations, we selected the voxels that were assigned a sand lithology. Next, we calculated another 10 simulations for these selected voxels, using only the borehole data with known grain-size estimates, resulting in 100 simulations of sand grain sizes in total. The same procedure was applied to 10 simulations of non-sand voxels. The 100 simulations of sand voxels were finally combined with the 100 simulations of non-sand voxels, resulting in 100, statistically equally probable simulations of lithological distributions. Analogously to the lithofacies modelling, probabilities for each lithology were calculated and subsequently used to compute a mean lithological model using the averaging method described by Soares (1992).

\section{Results}

\section{Stacked lithostratigraphical layer model}

Figure 8 shows the 2D raster layers of the base of each of the Holocene units, along with their respective area and volume. When combined, these basal surfaces constitute a consistent 3D stacked layer model (Fig. 9). The consistency of the model is for example illustrated by the deep tidal channels of the Walcheren Member (Fig. 8c) that incise into older deposits (Figs 8 d-f). Top surfaces (not shown in Fig. 8) of each lithostratigraphical unit are constructed by combining all overlying basal surfaces.
Figure 9 shows a 3D view of the stacked lithostratigraphical layer model. The model shows the gently dipping Neogene and Pleistocene strata overlain by the Holocene coastal, tidal and organic units. The model also shows the outcropping pre-Holocene units (e.g., Brabantse Wal escarpment) that occur in the south and east. The positions of the present water carrying channels of the 0osterschelde and Westerschelde are clearly visible as well as the coastal units (Zandvoort and Schoorl Members) in the west.

The spatial variation of the modelled Holocene stratigraphic units is also depicted in two cross sections that are representative for the model. The first cross section runs NW-SE across Schouwen and the 0osterschelde estuary, illustrating the geometry of the coastal Zandvoort and Schoorl Members (a-a' in Fig. 10a). The second cross section runs W-E across the former islands of Walcheren and Zuid-Beveland, illustrating the modelled geometry of the Basisveen Bed and the Wormer, Hollandveen and Walcheren Members (b-b' in Fig. 10a).

The model clearly shows how the Neogene-Pleistocene substratum, if not dissected, is covered by the Basisveen Bed and younger Holocene units (Fig. 10a). Locally, the NeogenePleistocene sediments as well as the Basisveen Bed are strongly dissected by the Holocene tidal channels of the Wormer and Walcheren Members, the latter being separated by the more or less continuous Hollandveen Member (Fig. 10a). The modelled channels of the Walcheren Member, like the Westerschelde estuary, are the most deeply incised features known from this area (Figs 8c, 10a), reaching depths up to $60 \mathrm{~m}$ below Dutch Ordnance Datum. Fig. 10 shows several locations where the Walcheren channels reactivate existing channels of the Wormer Member. 

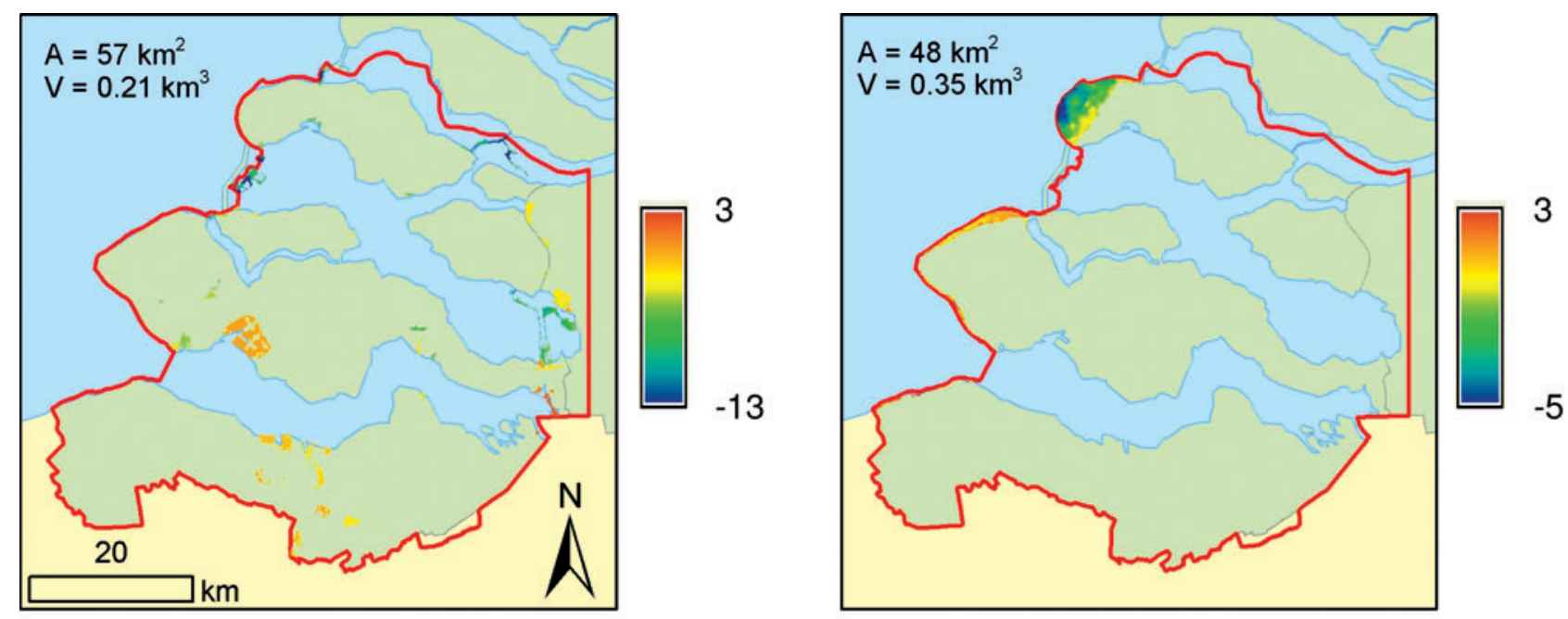

a. Anthropogenic
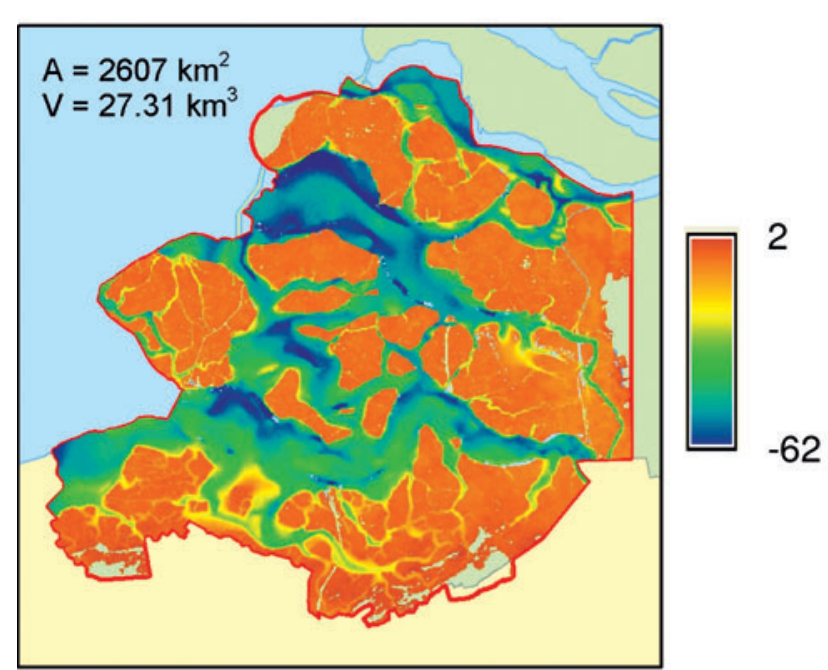

c. Walcheren Member

b. Schoorl Member

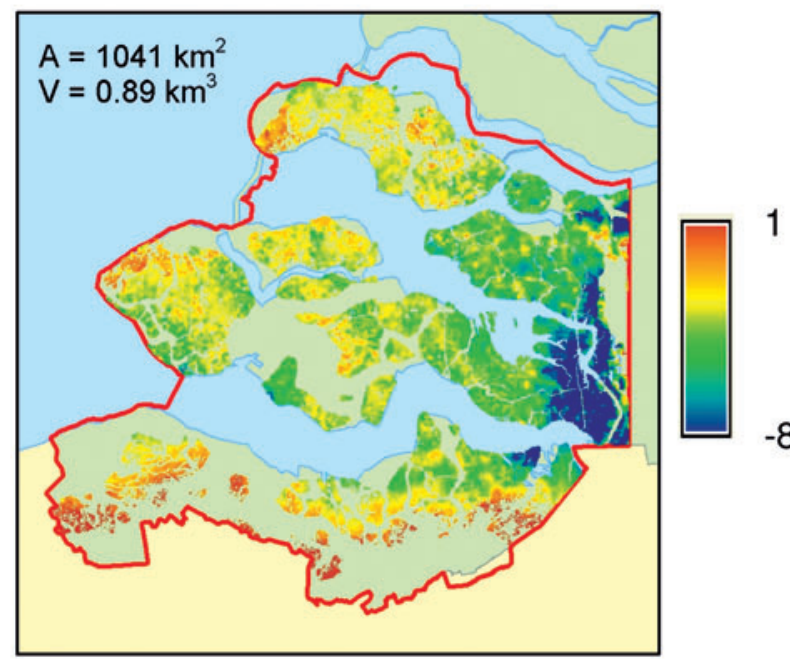

d. Hollandveen Member
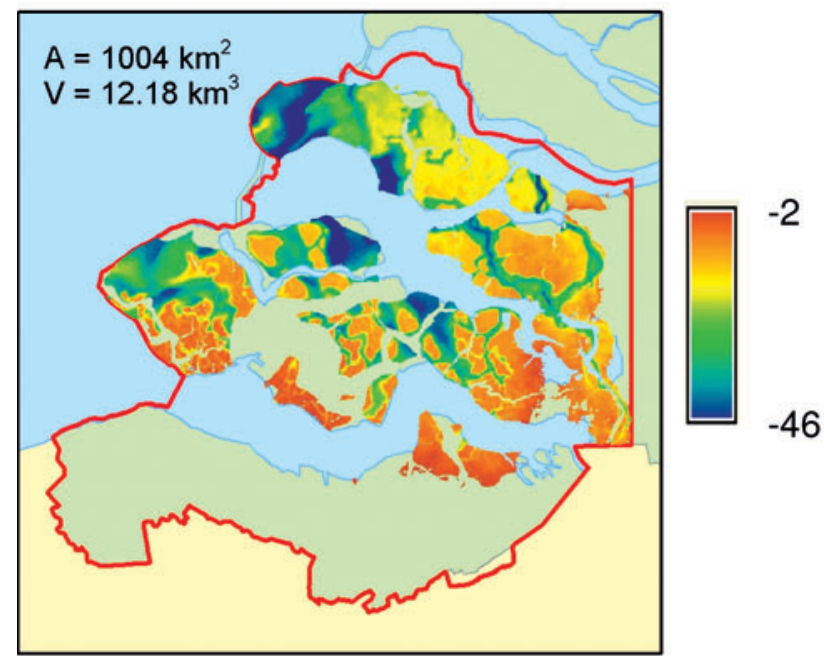

e. Wormer-Zandvoort Member

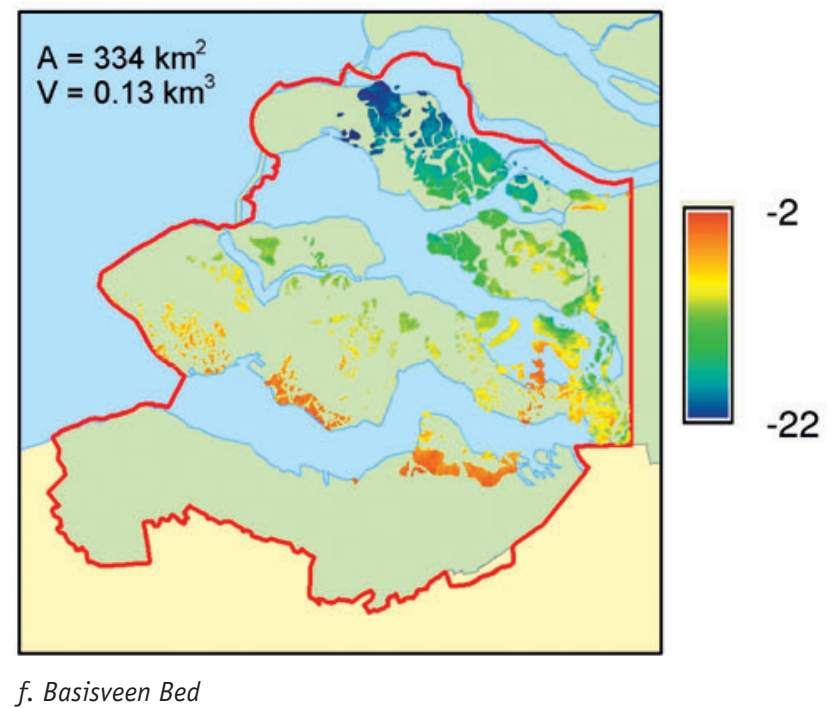

Fig. 8. Maps showing the depth in metres below Dutch Ordnance Datum of the base of each of the six Holocene lithostratigraphical units. Numbers indicate volume and area of each of the units. See text for discussion. 


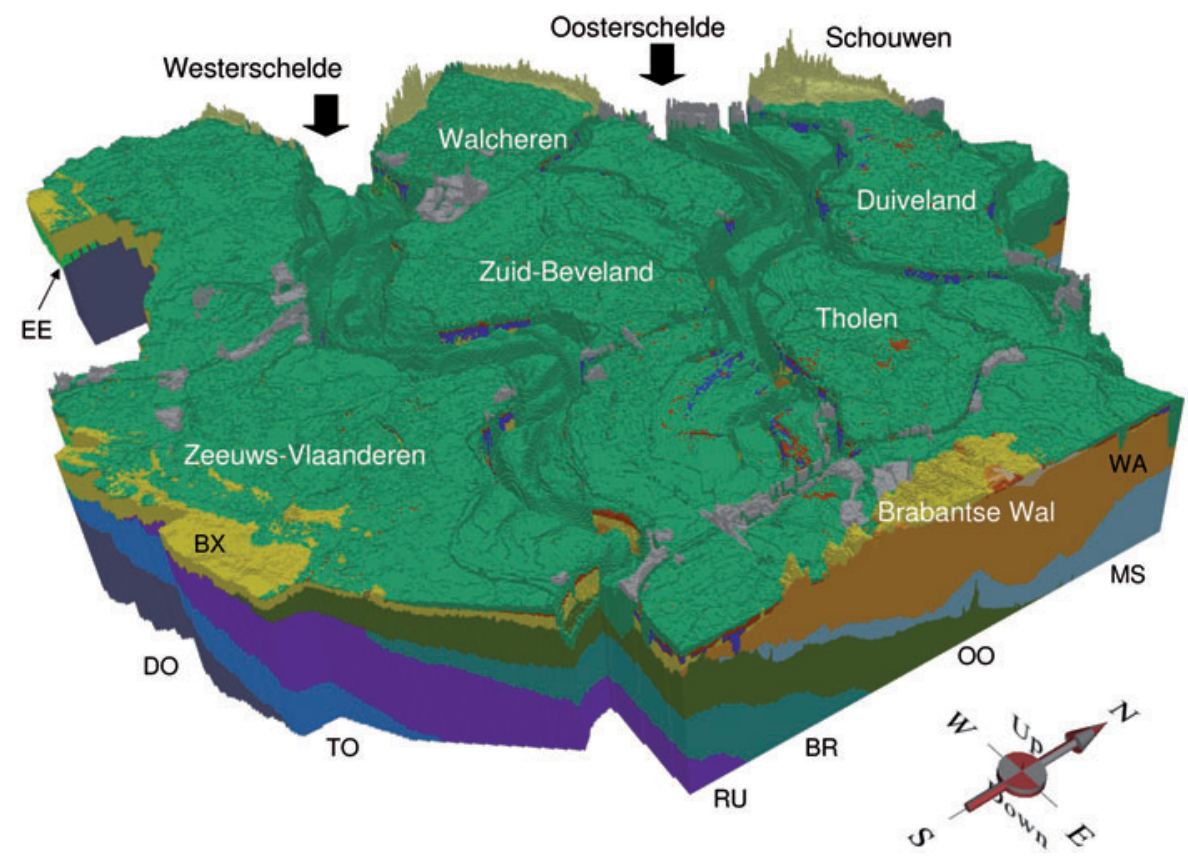

Fig. 9. 3D view of the stacked lithostratigraphical layer model of the Province of Zeeland. The model clearly shows the northward dipping Neogene and Pleistocene strata and overlying Holocene sediments. The surface geology is dominated by the tidal deposits of the Walcheren Member (green), the coastal dunes of the Schoorl Member (yellow) and anthropogenic sediments (grey). Key for older formations: BX-Boxtel, EE - Eem, WA - Waalre, MS - Maassluis, 00 - Oosterhout, BR - Breda, RU - Rupel, TO - Tongeren, DO - Dongen. Geographical names are referred to in the text.
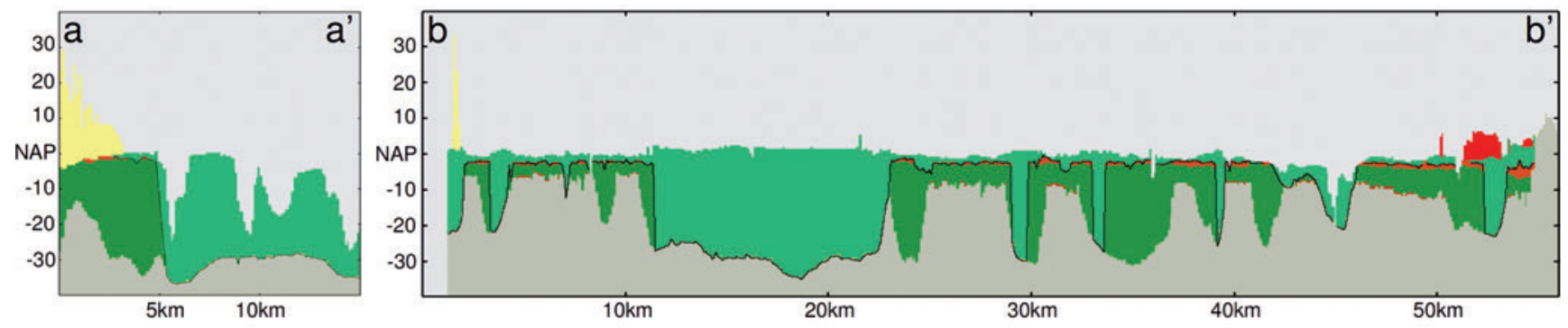

a. Lithostratigraphy
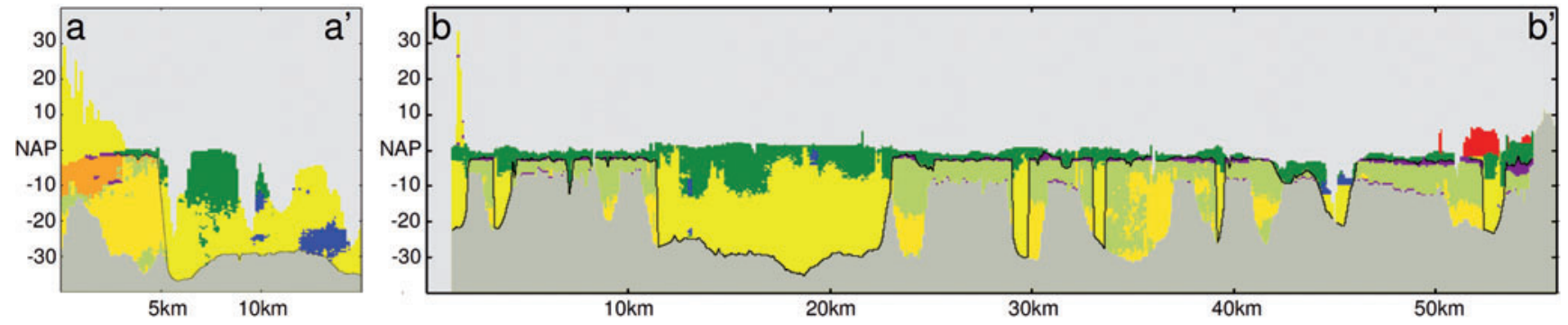

b. Lithofacies
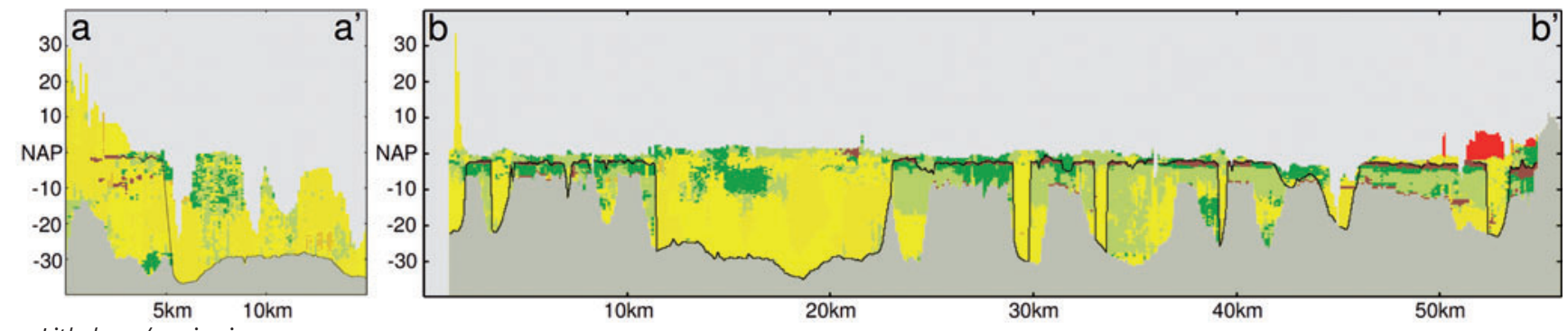

c. Lithology / grain size

Fig. 10. East-west cross sections through the 3D model showing: a. Lithostratigraphical units; $b$. Lithofacies distribution; and c. Lithology and sand grain sizes. The cross section on the left ( $a-a^{\prime}$ in Fig. $1 b$ ) runs NW-SE across Schouwen and the Oosterschelde estuary; the cross section on the right runs W-E across the former islands of Walcheren and Zuid-Beveland (b-b' in Fig. 1b). For legend see Fig. 12; the black line indicates the base of the Walcheren Member. 


\section{Lithofacies and lithological classification}

For the Holocene lithostratigraphical units, the distribution and volume of each lithofacies unit, as these were identified in the boreholes, are shown in Table 2.

The majority of the Wormer Member consists of clay deposited in tidal lagoons and mudflats. The clays occur at different levels throughout the unit. Other parts of this unit are made up of tidal deposits that could not be further separated into tidal flat and tidal channel deposits. The Walcheren Member shows both tidal channels and tidal flats. Note that the percentages of tidal flats are higher in the boreholes than in the model (the opposite is observed for tidal channel) because more boreholes were drilled within the shallow tidal flats than in the deeper located tidal channels. Shell rich material is locally present in minor quantities in the channels of the Westerschelde estuary. The Zandvoort Member (beach and shoreface), the Hollandveen Member (marshes) and Basisveen Bed (marshes) were all assigned a single lithofacies unit. The Schoorl Member consists almost entirely of aeolian dunes, with a few intercalations of peat.

The distribution of lithology and sand grain sizes for each of the Holocene lithostratigraphical units is shown in the bar graphs in Fig. 11. In case of the Wormer-Zandvoort and Walcheren Members, bar graphs of each lithofacies unit within these Members are shown. The Schoorl Member, Zandvoort Member and the tidal channels of the Walcheren Member are dominated by sands. The lagoons of the Wormer Member and the tidal flats of the Walcheren Member are dominated by clayey sediments while the tidal deposits of the Wormer Member are of an intermediate nature.

Table 2. Distribution of lithofacies units as occurring in the boreholes and as occurring in the $3 \mathrm{D}$ model. Note that the percentages of tidal flats are higher in the boreholes than in the model (the opposite is observed for tidal channels) because more boreholes were drilled within the shallow tidal flats than in the deeper located tidal channels.
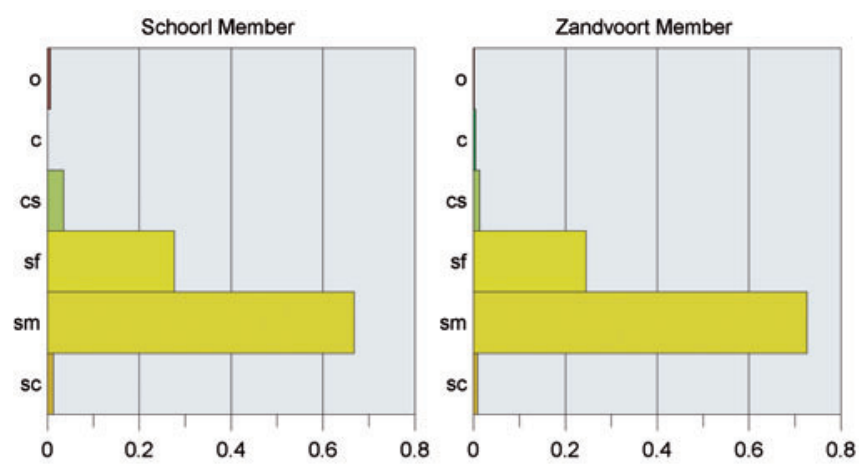

Walcheren Member - Tidal channel deposits

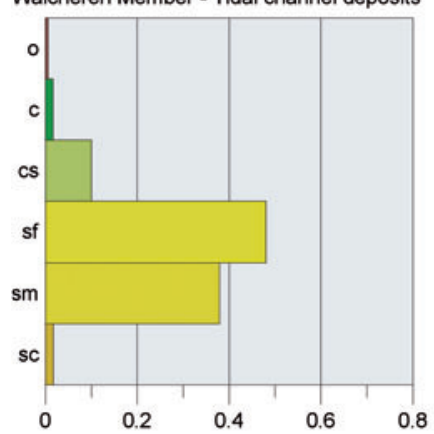

Walcheren Member - Tidal flat deposits
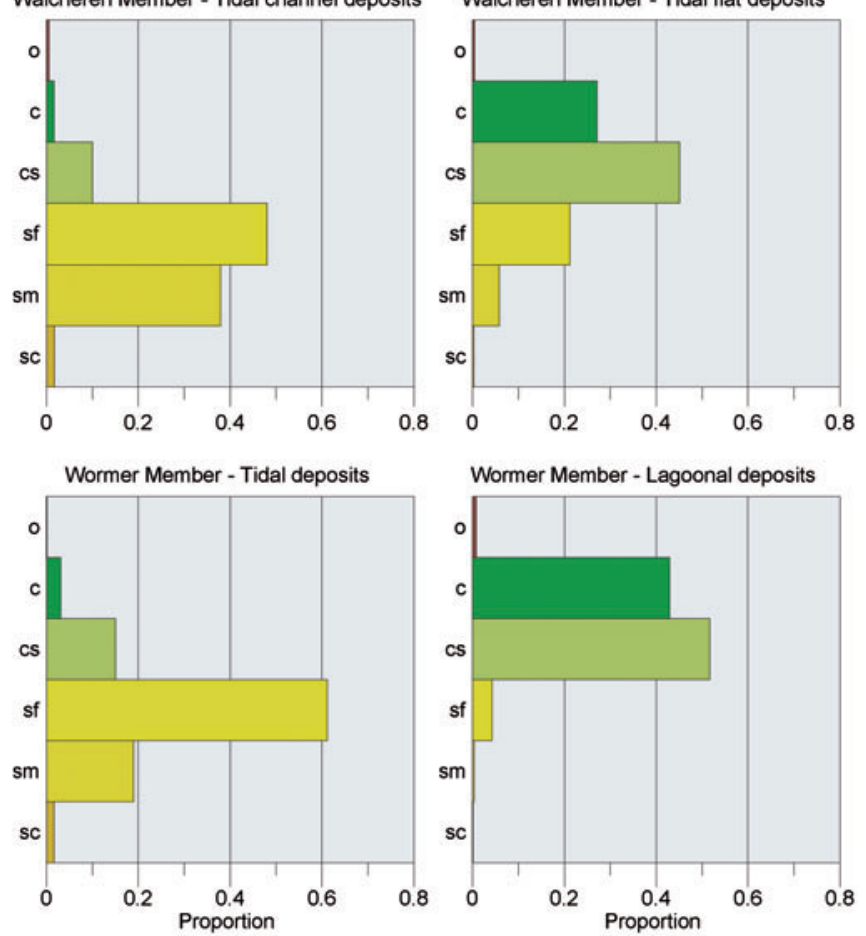

Fig. 11. Bar graphs showing the distribution of lithology and sand grain sizes for each of the lithostratigraphical units and, in case of the combined Wormer and Zandvoort Members and the Walcheren Member, for each lithofacies unit. Data are derived from boreholes. Key: $0=$ organic deposits; $c=$ clay; $c s$ = clayey sand and sandy clay; $s f=$ fine sand; $s m=$ medium sand; $s c=$ coarse sand, shells and gravel.

\begin{tabular}{|c|c|c|c|c|c|}
\hline $\begin{array}{l}\text { Lithostratigraphical } \\
\text { unit }\end{array}$ & Lithofacies unit & $\begin{array}{l}\text { Distribution of } \\
\text { lithofacies in cores } \\
\text { (m core length) }\end{array}$ & $\begin{array}{l}\text { Distribution of } \\
\text { lithofacies in cores } \\
(\%)\end{array}$ & $\begin{array}{l}\text { Distribution of } \\
\text { lithofacies in model } \\
\left(\mathrm{km}^{3}\right)\end{array}$ & $\begin{array}{l}\text { Distribution of } \\
\text { lithofacies in model } \\
(\%)\end{array}$ \\
\hline \multirow[t]{2}{*}{ Schoorl Member } & Dunes & 584 & 99.7 & 0.35 & 99.4 \\
\hline & Marshes & 2 & 0.3 & 0.00 & 0.6 \\
\hline Zandvoort Member & Beach and shoreface & 907 & 100 & 0.14 & 100 \\
\hline \multirow[t]{3}{*}{ Walcheren Member } & Tidal flats & 60196 & 63 & 9.15 & 33.5 \\
\hline & Tidal channels & 31467 & 33 & 17.18 & 62.9 \\
\hline & Shell-rich tidal channels & 3842 & 4 & 0.98 & 3.6 \\
\hline Hollandveen Member & Marshes & 11768 & 100 & 0.89 & 100 \\
\hline \multirow[t]{2}{*}{ Wormer Member } & Lagoons & 45363 & 65 & 7.59 & 63.1 \\
\hline & Tidal flats and tidal channels & 24846 & 35 & 4.44 & 36.9 \\
\hline Basisveen Bed & Marshes & 678 & 100 & 0.13 & 100 \\
\hline
\end{tabular}




\section{D lithofacies and lithological model}

Figure $10 \mathrm{~b}$ shows that within the channels of the Wormer Member, the tidal deposits occur at the base. Significant amounts of lagoonal lithofacies occur higher up in the unit and at locations where the unit is thin (Table 2). For the Walcheren Member the tidal channels define the lower part of the unit while extensive amounts of tidal flats occur higher up in the unit and at locations where the unit is thin. Figure 10c shows that in general, the tidal channels of the Wormer Member are finer grained than those of the Walcheren Member. For the former, the coarsest sediments primarily occur towards the base of the channels while in the Walcheren Member the occurrence of coarser material is not restricted to a specific depth.

The spatial variation of lithostratigraphy, lithofacies and lithology is further illustrated in 3D views of the former island of Schouwen and the 0osterschelde estuary (Fig. 12). The main lithostratigraphical units in this area are the Walcheren Member and the dunes in the western part of Schouwen (Schoorl Member; Fig. 12a). The dunes overlie deposits of the combined Wormer-Zandvoort Member. The large grey area in the Oosterschelde represents the anthropogenic sediments underlying the storm surge barrier.
In the foreground of Fig. 12b, we can see a large sandy channel system (yellow) that follows the present-day outline of the Oosterschelde estuary. Blue colours in the channel indicate that locally shells and shell-rich sands occur. On the former island of Schouwen, the Walcheren Member mainly consists of thin layers of tidal flat deposits (green). Beach and shoreface deposits of the Zandvoort Member are visible underneath the dunes of Schouwen (orange).

Figure 12c shows the same area but now with the results of the lithological modelling. The lithological model shows some elongated zones of coarse sand dominance. The general picture however does not show clear patterns or trends in terms of lithological and grain-size variation, a finding that is similar to the observations made in the cross sections of Fig. $10 \mathrm{~b}$.

\section{Model uncertainty}

Figure 13b shows the probability calculation results for lithofacies tidal channel (Fig. 13a) in the Walcheren Member. The colours indicate the probability that a voxel contains the tidal channel lithofacies. At the centre of the channel, this probability is high $(100 \%)$. In the upper part of the channel, the green and yellow colours reveal smaller probabilities. In this upper part, we expect more tidal flat deposits. Similarly,

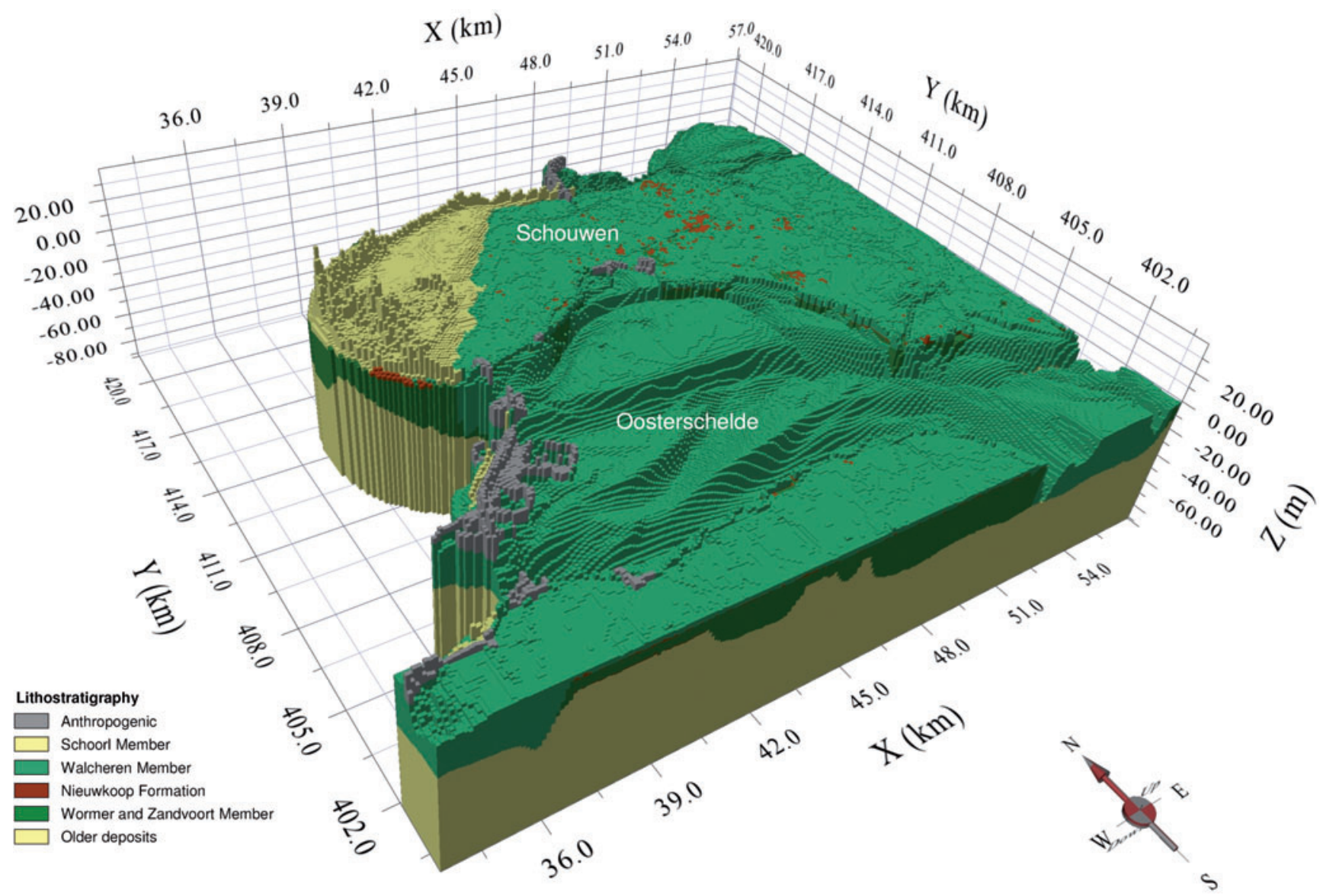

Fig. 12. 3D views of: $a$. Lithostratigraphy; b. Lithofacies; and c. Lithology and sand grain-size classes in the area of Schouwen and the Oosterschelde estuary. See text for discussion. 


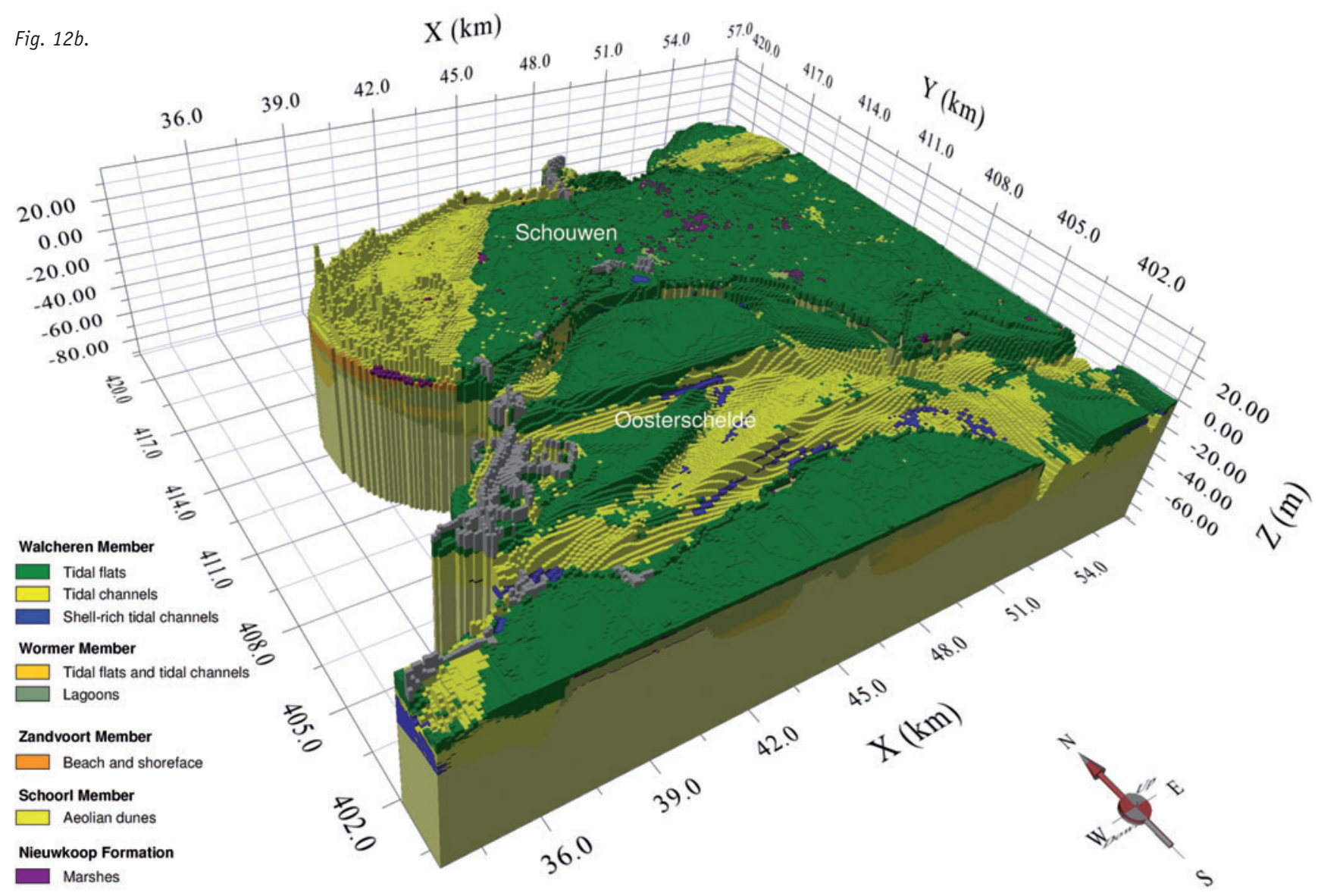

Other

$\square$ Anthropogenic

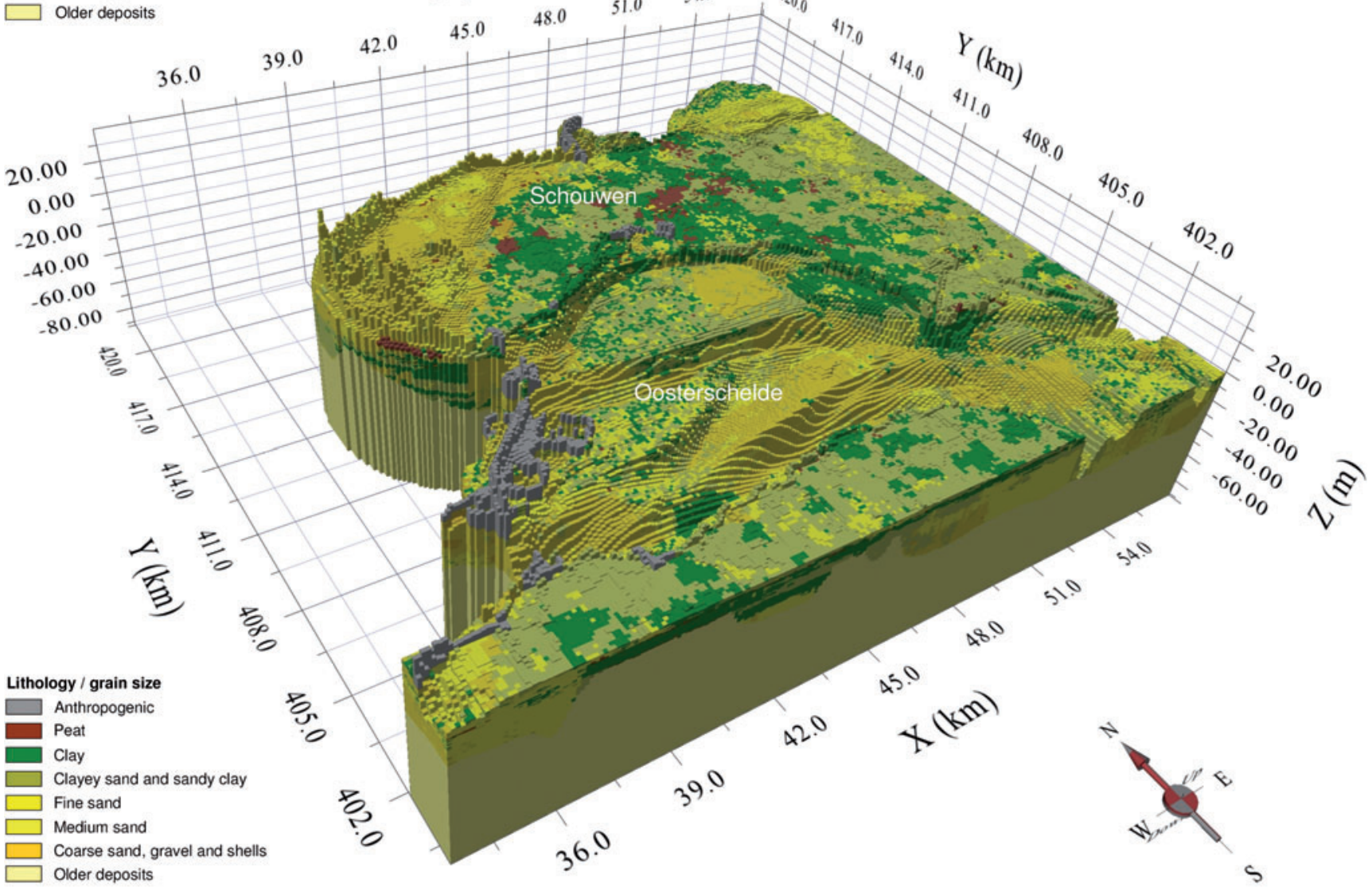

Fig. $12 c$. 

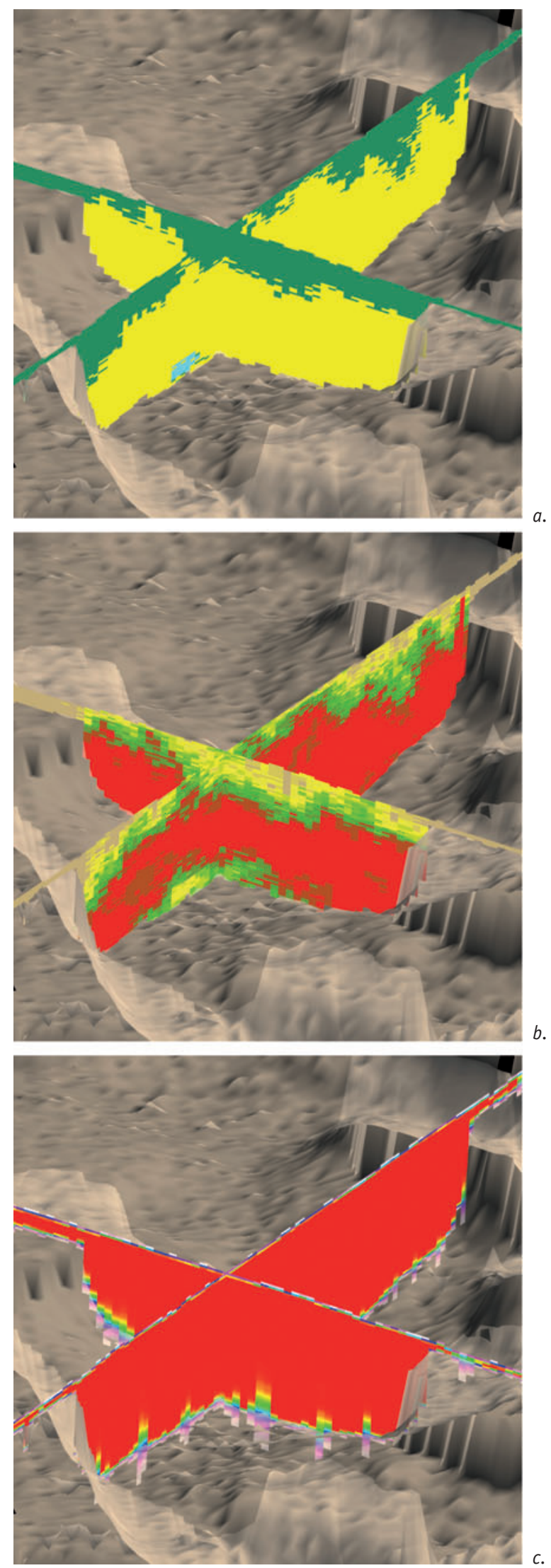

Fig. 13. Cross sections through a tidal channel in the Walcheren Member showing: $a$. Lithofacies; $b$. Probability that a voxel belongs to the tidal channel lithofacies; c. Probability that a voxel is part of the Walcheren Member. we see lower probabilities at the bottom of the channel, where we would expect shells and shell-rich sands.

Figure $13 \mathrm{c}$ shows that the probability that this particular unit belongs to the Walcheren Member is high (red) in its centre while the probability becomes smaller going towards the top and base of the unit.

It should be noted that the probabilities in Fig. 13 provide a measure of model uncertainty only. Data uncertainty (for instance errors in borehole location and errors in depth and grain-size estimates) is not represented by these probabilities.

\section{Secondary products for applications}

Visualising and exploring 3D property models requires sophisticated software packages such as Isatis, GoCad and Petrel. These software packages are expensive, often difficult to operate, and in many cases not available to the user community. We therefore provide the users of our models with secondary products that are derived from the 3D model. These secondary products include 2D maps that can be viewed and analyzed in desktop GIS, such as the layer model in Fig. 8, and cross sections such as Fig. 10.

Other examples of 2D maps are series of horizontal slices through the 3D model, displaying the model properties like lithostratigraphy, lithofacies, lithology class and probabilities at a certain depth below Dutch Ordnance Datum or below land surface. Figure 14 shows an example of slices through the lithology and sand grain-size model at depths of $0,-2,-4,-6$ and $-8 \mathrm{~m}$ Dutch Ordnance Datum. Clearly visible in these slices are the position of the tidal channels (sands) and adjacent zones of tidal flats (clays) and zones where peat occurs.

A special case is the surface geological map which can be derived from the 3D model by plotting the lithostratigraphical units at land surface (i.e. a top view of Fig. 9). The surface geological map can easily be extended with so-called sub crop maps where shallower geological units are removed in order to reveal deeper units. Another example is a map showing the cumulative thickness of sands and shells as a potential source of aggregates (Fig. 15).

All secondary products are freely available for downloading on the website www.dinoloket.nl.

\section{Discussion}

\section{The key role of standardisation}

The GeoTOP modelling approach relies heavily on the relational DINO database containing a carefully maintained dataset of standardised geological information of the Netherlands. At present this database contains some 450,000 borehole descriptions as well as other types of data. Development of the database started in the early nineties when the first borehole descriptions were digitised. The main set of borehole data was 

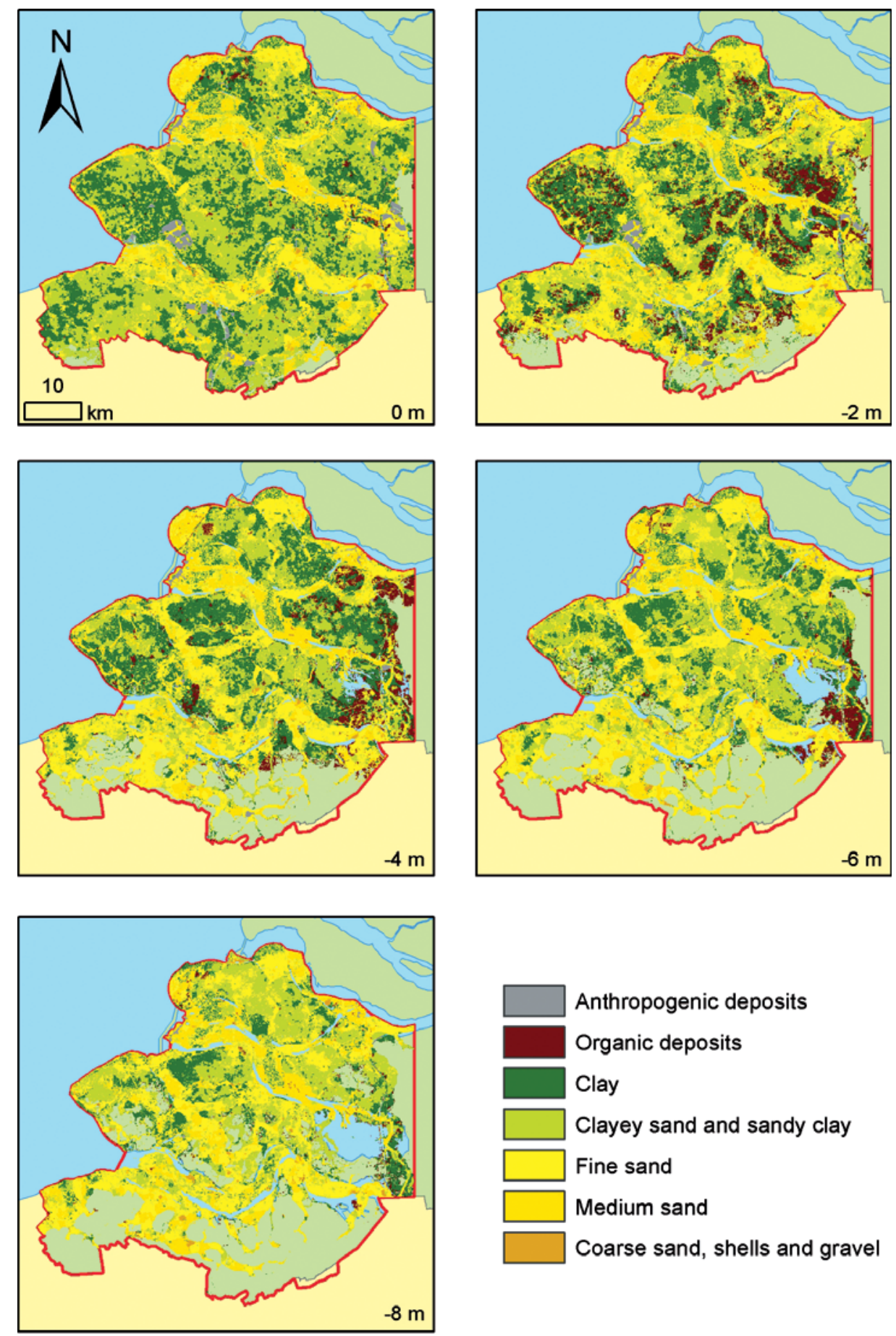

Fig. 14. Horizontal slices through the lithofacies model at particular depths below Dutch Ordnance Datum revealing the position of tidal channels in the Walcheren Member.

collected by the Geological Survey during the 1 : 50,000 mapping campaign that lasted for about 40 years and ended in 2000 . Most of the other borehole data comes from external parties like groundwater companies and municipalities.

Because different types of borehole descriptions had to be combined during designing and filling of the database, standardised data formats were developed for a uniform description of borehole lithology, grain size and admixture information. Several systems existed throughout the years but at present, all data is available in the SBB 5.1 coding system (Bosch, 2000).
The Geological Survey also developed a standardised lithostratigraphical coding system. The latest system, published by Westerhoff et al. (2003), is a revision of the classification of Doppert et al. (1975). The new system better follows lithostratigraphical rules of macroscopic recognition and mapability, allowing a more practical use in lithostratigraphical coding.

Both the well maintained DIN0 database and the standardised coding systems strongly facilitated the construction of a uniform dataset for the GeoTOP model of Zeeland. Without these standardised systems, which took decades to develop, the modelling would not have been possible. 


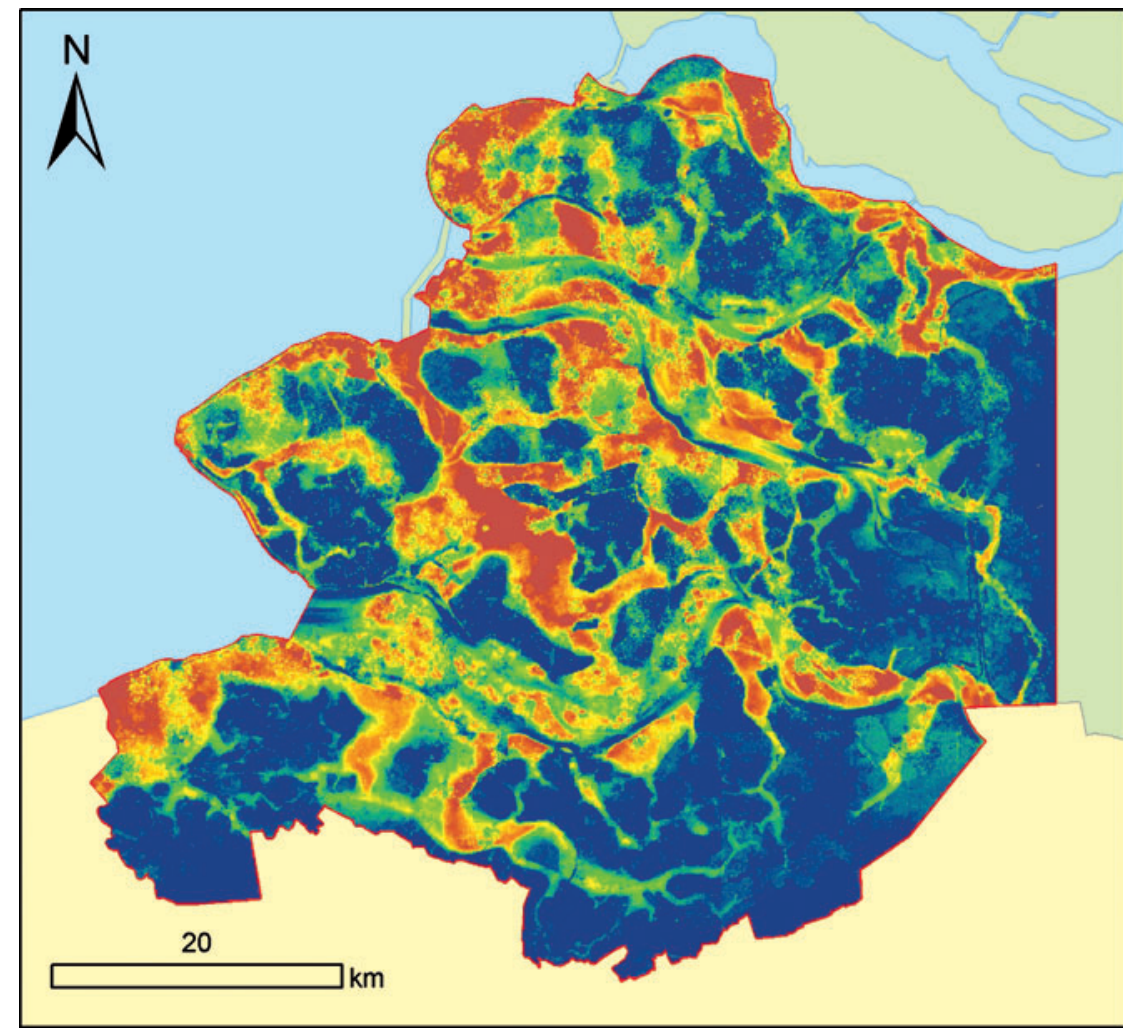

\section{Thickness}

(m)

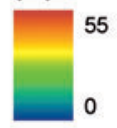

\section{Lithofacies interpretation}

The lithofacies interpretation was applied in an automated way to some 23,000 boreholes. This method has the great advantage that a large amount of data can be processed in a short time. However, due to varying data quality of the borehole descriptions, it was not always possible to distinguish the lithofacies units known to be present on the basis of geological mapping (Schokker \& Weerts, 2004). For example, in good quality cored boreholes, tidal channel deposits in the Wormer Member can be recognised by the presence of features such as cross bedding. However, cross bedding is only described in a limited number of boreholes and therefore not usable as a general criterion in an automated procedure. We were therefore forced to combine the tidal channels and tidal flats into a single lithofacies unit. In case of the Walcheren Member, however, the lithofacies interpretation of the borehole data using a combination of stratigraphical and lithological criteria was the key to successfully outline the location, top and bottom of the tidal channels.

\section{Lithological classification}

The classification scheme we have used is identical to the one in REGIS, and is aimed at hydrological applications such as groundwater modelling and studies of salt water penetration. Other applications often require alternative classification schemes. For example, the exploration for aggregate resources like sand and shells require different grain-size class intervals
(Van der Meulen et al., 2005). Other possible classifications may be aimed at chemical applications, for instance the study of areas that are vulnerable to pollution, and engineering geology, for answering subsurface related questions in large-scale infrastructural works such as the construction of dams and dykes. This implies that several lithological classifications should be used in the modelling in order to meet the user's needs.

\section{Physical and chemical properties}

In addition to the modelling described in this paper, the Geological Survey of the Netherlands collects and measures physical and chemical parameters from core material. The sampling strategy is such that measured values can be assigned to lithostratigraphical, lithofacies and lithological units, making it possible to obtain insights into the spatial variability of physical and chemical properties in three dimensions. Examples of physical and chemical parameters include horizontal and vertical hydraulic conductivity, which are crucial in groundwater models, and the reactivity of sediments, which is used in the modelling of contaminant plumes.

The Zeeland model serves as a source of subsurface information and provides the regional, geological composition as well as the spatial variability in lithology and sedimentation patterns. This model currently uses the lithological classification scheme identical to the one used in REGIS, which makes it possible, using the measured physical hydrological properties, to construct a parameterised hydrological model including estimates of uncertainty. 


\section{Developments and outlook}

In the past decades mapping has slowly evolved into modelling. GeoTOP is so far the latest step in this process. Although the maps constructed by Hageman $(1963,1964,1969)$, Van Rummelen $(1965,1972)$ and Vos (1992) already show the vertical succession of Holocene deposits by means of their sophisticated legend, GeoTOP has significant advantages over these maps. Because of the almost fully automated workflow new insights and/or new data can easily be incorporated into the model. Moreover the creation of secondary products is straightforward, leading for example to the real-time construction of cross sections on any chosen location, a great advantage compared to the amount of time needed to construct these cross sections by hand.

The GeoTOP model captures sedimentary architecture down to the detail level of depositional units such as barrier and tidal systems. At the chosen voxel resolution, there is still a considerable residual heterogeneity, associated with smallerscale phenomena such as bedforms. Such heterogeneity needs to be better resolved for an adequate appraisal of, for example, hydrological and geotechnical behaviour. However, borehole data density is a limiting factor, and it is therefore worthwhile to explore using other data types. At present, effort is put in incorporating cone penetration test data: if successful this would make a very large set of data available to GeoTOP modelling. Other data types under consideration are high resolution seismic profiling, ground penetrating radar and airborne electromagnetic prospecting.

The Dutch ministry of housing, spatial planning and the environment is currently drafting a new law, which will put subsurface data and information in the system of so-called key registries ('basisregistraties'). These are sets of data that are considered vital to the Dutch private and public sectors, and to the general public. Key registries are managed nationally and have official status of authenticity. Governmental organisations are legally obliged to deliver data to the key registries, and the data have to be consulted in certain planning and decision making processes.

The key registry for the subsurface ('basisregistratie ondergrond'), to be managed by the Geological Survey of the Netherlands, will hold subsurface data, including model data such as DGM, REGIS and GeoTOP, as well as information on permits and underground infrastructure. The obligatory delivery of data is expected to substantially enlarge our borehole and cone penetration test databases, resulting in more accurate GeoTOP models. The obligatory consultation will increase and formalise the Survey's accountability and responsibility associated with its modelling efforts, potentially up to the level of liability. Model reliability will have to be better resolved: while we presently limit ourselves to calculating voxel attribute probabilities based on multiple model realisations, we will eventually have to address data uncertainty, and possibly the propagation of errors to downstream applications.

\section{Conclusions}

The Zeeland GeoTOP model is the first fully 3D regional-scale lithofacies and lithological class model of the upper tens of metres of the Dutch subsurface. In addition, the model provides a first measure of uncertainty associated with the model outcomes.

The model's almost fully automated workflow makes it easy to incorporate new insights and/or data and to produce secondary products for applications, giving GeoTOP significant advantages over previous models and traditional geological maps.

The Zeeland modelling is a major step forward towards a full 3D voxel model of the subsurface of the Netherlands. We are currently extending the models towards the north, east and south of the Netherlands, ultimately leading to a full model cover of the Netherlands $\left(41,000 \mathrm{~km}^{2}\right)$.

\section{Acknowledgements}

We thank Ronald Vernes, Michiel van der Meulen, Dick van Doorn and Patrick Kiden for fruitful discussions. Harvey Thorleifson and Dick Brus are thanked for reviewing the manuscript. Thanks are also due to Wim Westerhoff and Jeroen Schokker for their comments. The results of the GeoTOP Zeeland model are freely available for downloading, on the website www.dinoloket.nl.

\section{References}

Beets, D.J. \& Van der Spek, A.J.F., 2000. The Holocene evolution of the barrier and the back-barrier basins of Belgium and The Netherlands as a function of late Weichselian morphology, relative sea-level rise and sediment supply. Geologie en Mijnbouw / Netherlands Journal of Geosciences 79: 3-16.

Bosch, J.H.A., 2000. Standaard Boor Beschrijvingsmethode. Netherlands Institute of Applied Geosciences TN0, Report NITG 00-141-A.

Bogaert, $\boldsymbol{P}$., 2002. Spatial prediction of categorical variables: the Bayesian maximum entropy approach. Stochastic Environmental Research and Risk Assessment SERRA, 6, 6: 425-448.

Doppert, J.W.Chr., Ruegg, G.H.J., Van Staalduinen, C.J., Zagwijn, W.H. \& Zandstra, J.G., 1975. Formaties van het Kwartair en Boven-Tertiair in Nederland. In: Zagwijn, W.H. \& Van Staalduinen, C.J. (eds): Toelichting bij geologische overzichtskaarten van Nederland. Rijks Geologische Dienst, Haarlem: 11-56.

Goovaerts, P., 1997. Geostatistics for Natural Resources Evaluation. Oxford University Press, New York, 483 pp.

Hageman, B.P., 1963. De profieltype-legenda van de nieuwe geologische kaart voor het zeeklei- en rivierkleigebied. Tijdschrift voor het Koninklijk Nederlands Aardrijkskundig Genootschap, Tweede Reeks 80: 217-229.

Hageman, B.P., 1964. Blad Goeree en Overflakkee, Toelichting bij de Geologische Kaart van Nederland, $1: 50.000$. Rijks Geologische Dienst Haarlem, 89 pp.

Hageman, B.P., 1969. Development of the western part of the Netherlands during the Holocene. Geologie en Mijnbouw 48, 373-388. 
Kasse, C., 1988. Early Pleistocene tidal and fluvial environments in the southern Netherlands and northern Belgium. Ph.D. dissertation, Vrije Universiteit Amsterdam, $190 \mathrm{pp}$.

Kiden, $\boldsymbol{P} ., 1995$. Holocene relative sea-level change and crustal movement in the southwestern Netherlands. Marine Geology, 124: 21-41.

Kooi, H., Johnston, P., Lambeck, K., Smither, C. \& Molendijk, R., 1998. Geological causes of recent ( $100 \mathrm{yr})$ vertical land movement in the Netherlands. Tectonophysics, 299, 297-316.

Miall, A.D., 1999. Principles of sedimentary basin analysis (3 ${ }^{\text {rd }}$ ed.). Springer, Berlin, $616 \mathrm{pp}$.

Soares, A., 1992. Geostatistical estimation of multi-phase structure. Mathematical Geology 24: 149-160.

Schokker, J. \& Weerts, H.J.T., 2004. Afzettingsmilieus en faciëseenheden van de Tertiaire en Kwartaire lithostratigrafische eenheden in de ondergrond van Nederland. Netherlands Institute of Applied Geosciences TNO, Report 03-194-A, $31 \mathrm{pp}$.

Schokker, J., Weerts, H.J.T., Westerhoff, W.E., Berendsen, H.J.A. \& Den Otter, C., 2007. Introduction of the Boxtel Formation and implications for the Quaternary lithostratigraphy of the Netherlands. Netherlands Journal of Geosciences / Geologie en Mijnbouw 86: 197-210.

Strebelle, S., 2002. Conditional Simulation of Complex Geological Structures Using Multiple-Point Statistics. Mathematical Geology, 34: 1-21.

Van der Meulen, M.J., Van Gessel, S.F. and Veldkamp, J.G., 2005. Aggregate resources in the Netherlands. Netherlands Journal of Geosciences, 84: 379-387.

Van der Meulen, M.J., Maljers, D., Van Gessel, S.F. \& Gruijters, S.H.L.L., 2007. Clay resources in the Netherlands. Netherlands Journal of Geosciences, 86: 117-130.

Van Rummelen, F.F.F.E., 1965. Zeeuwsch Vlaanderen, Bladen Zeeuwsch Vlaanderen, West en Oost, Toelichting bij de Geologische Kaart van Nederland, 1 : 50.000. Rijks Geologische Dienst Haarlem, 79 pp.

Van Rummelen, F.F.F.E., 1972. Blad Walcheren, Toelichting bij de Geologische kaart van Nederland 1:50.000. Rijks Geologische Dienst, Haarlem, 120 pp.

Vernes, R.W., Hummelman, H.J. \& Menkovic, A., 2010. REGIS Zeeland, Deelrapport B: Hydrogeologische opbouw en hydraulische eigenschappen van Holocene afzettingen. TN0, Report 034-UT-2010-01647/A, 74 pp.

Vernes, R.W. \& Van Doorn, Th.H.M., 2005. Van Gidslaag naar Hydrogeologische Eenheid - Toelichting op de totstandkoming van de dataset REGIS II. Netherlands Institute of Applied Geosciences TN0, Report 05-038-B, 105 pp.

Vos, P.C., 1992. Toelichting kaartblad 43/49 West en 49 0ost - Concept toelichting 43/49 West: Holocene deel. Dienstrapport 1454, Rijks Geologische Dienst, Haarlem, $41 \mathrm{pp}$.

Vos, P.C. \& Van Heeringen, R.M., 1997. Holocene geology and occupation history of the Province of Zeeland. In: Fischer, M.M. (ed.): Holocene evolution of Zeeland (SW Netherlands), 5-110.

Weerts, H.J.T., Westerhoff, W.E., Cleveringa, P., Bierkens, M.F.P., Veldkamp, J.G. and Rijsdijk, K.F., 2005. Quaternary geological mapping of the lowlands of the Netherlands, a $21^{\text {st }}$ century perspective. Quaternary International, 133-134: 159-178.

Westerhoff, W.E., 2009. Stratigraphy and sedimentary evolution. The lower Rhine-Meuse system during the Late Pliocene and Early Pleistocene (southern North Sea Basin). Ph.D. dissertation, Vrije Universiteit Amsterdam, $168 \mathrm{pp}$.
Westerhoff, W.E., Wong, Th.E. \& Geluk, M.C., 2003. De opbouw van de ondergrond. In: De Mulder, E.F.J., Geluk, M.C., Ritsema, I., Westerhoff, W.E. \& Wong, Th.E. (eds): De ondergrond van Nederland. Nederlands Instituut voor Toegepaste Geowetenschappen TN0, Geologie van Nederland 7: 247-352.

Ziegler, P.A., 1990. Geological atlas of Western and Central Europe. $3^{\text {rd }}$ edition, Shell International Petroleum Maatschappij B.V., Geological Society, Bath, $239 \mathrm{pp}$.

Ziegler, P.A., 1994. Cenozoic rift system of western and central Europe: an overview, Geologie en Mijnbouw 73: 99-127. 